\title{
Vivianite formation in ferruginous sediments from Lake Towuti, Indonesia
}

\author{
Aurèle Vuillemin ${ }^{1, a}$, André Friese ${ }^{1}$, Richard Wirth ${ }^{1}$, Jan A. Schuessler ${ }^{1}$, Anja M. Schleicher ${ }^{1}$, Helga Kemnitz ${ }^{1}$, \\ Andreas Lücke $^{2}$, Kohen W. Bauer ${ }^{3, b}$, Sulung Nomosatryo ${ }^{1,4}$, Friedhelm von Blanckenburg ${ }^{1}$, Rachel Simister ${ }^{3}$, Luis \\ G. Ordoñez ${ }^{5}$, Daniel Ariztegui ${ }^{5}$, Cynthia Henny ${ }^{4}$, James M. Russell ${ }^{6}$, Satria Bijaksana ${ }^{7}$, Hendrik Vogel $^{8}$, Sean \\ A. Crowe ${ }^{3,9, b}$, Jens Kallmeyer ${ }^{1}$, and the Towuti Drilling Project Science team ${ }^{+}$ \\ ${ }^{1}$ GFZ German Research Centre for Geosciences, Helmholtz Centre Potsdam, 14473 Potsdam, Germany \\ ${ }^{2}$ Jülich Research Center, Institute of Bio- and Geosciences 3, Agrosphere, 52428 Jülich, Germany \\ ${ }^{3}$ Department of Earth, Ocean, and Atmospheric Sciences, University of British Columbia, Vancouver, BC, V6T 1Z4, Canada \\ ${ }^{4}$ Research Center for Limnology, Indonesian Institute of Sciences (LIPI), Cibinong-Bogor, Indonesia \\ ${ }^{5}$ Department of Earth Sciences, University of Geneva, Geneva, 1205, Switzerland \\ ${ }^{6}$ Department of Earth, Environmental, and Planetary Sciences, Brown University, 324 Brook Street, \\ Providence, RI 02912, USA \\ ${ }^{7}$ Faculty of Mining and Petroleum Engineering, Institut Teknologi Bandung, 15 Bandung, 50132, Indonesia \\ ${ }^{8}$ Institute of Geological Sciences and Oeschger Centre for Climate Change Research, \\ University of Bern, Bern, 3012, Switzerland \\ ${ }^{9}$ Department of Microbiology and Immunology, University of British Columbia, Vancouver, BC, V6T 1Z3, Canada \\ ${ }^{a}$ now at: Department of Earth and Environmental Science, Paleontology and Geobiology, \\ Ludwig-Maximilians-Universität München, 80333 Munich, Germany \\ ${ }^{b}$ now at: Department of Earth Sciences, University of Hong Kong, Hong Kong SAR, China \\ $\boldsymbol{+}_{\mathrm{A}}$ full list of authors appears at the end of the paper.
}

Correspondence: Aurèle Vuillemin (a.vuillemin@lrz.uni-muenchen.de)

Received: 24 October 2019 - Discussion started: 14 November 2019

Revised: 19 February 2020 - Accepted: 20 February 2020 - Published: 14 April 2020

\begin{abstract}
Ferruginous lacustrine systems, such as Lake Towuti, Indonesia, are characterized by a specific type of phosphorus cycling in which hydrous ferric iron (oxyhydr)oxides trap and precipitate phosphorus to the sediment, which reduces its bioavailability in the water column and thereby restricts primary production. The oceans were also ferruginous during the Archean, thus understanding the dynamics of phosphorus in modern-day ferruginous analogues may shed light on the marine biogeochemical cycling that dominated much of Earth's history. Here we report the presence of large crystals $(>5 \mathrm{~mm})$ and nodules $(>5 \mathrm{~cm})$ of vivianite - a ferrous iron phosphate - in sediment cores from Lake Towuti and address the processes of vivianite formation, phosphorus retention by iron and the related mineral transformations during early diagenesis in ferruginous sediments.
\end{abstract}

Core scan imaging, together with analyses of bulk sediment and pore water geochemistry, document a $30 \mathrm{~m}$ long interval consisting of sideritic and non-sideritic clayey beds and diatomaceous oozes containing vivianites. Highresolution imaging of vivianite revealed continuous growth of crystals from tabular to rosette habits that eventually form large (up to $7 \mathrm{~cm}$ ) vivianite nodules in the sediment. Mineral inclusions like millerite and siderite reflect diagenetic mineral formation antecedent to the one of vivianite that is related to microbial reduction of iron and sulfate. Together with the pore water profiles, these data suggest that the precipitation of millerite, siderite and vivianite in soft ferruginous sediments stems from the progressive consumption of dissolved terminal electron acceptors and the typical evolution of pore water geochemistry during diagenesis. Based on solute concentrations and modeled mineral saturation indices, 
we inferred vivianite formation to initiate around $20 \mathrm{~m}$ depth in the sediment. Negative $\delta^{56} \mathrm{Fe}$ values of vivianite indicated incorporation of kinetically fractionated light $\mathrm{Fe}^{2+}$ into the crystals, likely derived from active reduction and dissolution of ferric oxides and transient ferrous phases during early diagenesis. The size and growth history of the nodules indicate that, after formation, continued growth of vivianite crystals constitutes a sink for $\mathrm{P}$ during burial, resulting in long-term $P$ sequestration in ferruginous sediment.

\section{Introduction}

In the lacustrine realm, phosphorus $(\mathrm{P})$ is often the limiting nutrient for primary production (Compton et al., 2000). Its supply to primary producers in the euphotic zone depends on external fluxes (Manning et al., 1999; Zegeye et al., 2012) and internal recycling as a result of organic matter (OM) mineralization in both the water column and underlying sediments (Katsev et al., 2006; Hupfer and Lewandowski, 2008). Removal of $\mathrm{P}$ through burial in sediments depends partly on sorption to iron oxides (Wilson et al., 2010), and because iron oxides tend to dissolve under reducing conditions and long-term anoxia, phosphate burial is sensitive to the oxygenation state of the water column and water-sediment interface (Sapota et al., 2006; Rothe et al., 2015). In environments with high sulfate $\left(\mathrm{SO}_{4}^{2-}\right)$ concentrations and sufficient labile $\mathrm{OM}$, microbial $\mathrm{SO}_{4}^{2-}$ reduction usually leads to the formation of sulfides and eventually iron sulfides, which decrease $\mathrm{Fe}$ recycling and the formation of $\mathrm{Fe}$ (oxyhydr)oxides in the upper oxygenated sediments, and this in turn decreases the extent to which $\mathrm{P}$ is retained in the sediment (Roden and Edmonds, 1997). Formation of iron phosphate minerals such as vivianite (i.e., $\left.\mathrm{Fe}_{3}\left(\mathrm{PO}_{4}\right)_{2} \cdot 8 \mathrm{H}_{2} \mathrm{O}\right)$ in response to the accumulation of sedimentary Fe and P (Gächter et al., 1988; Wilson et al., 2010; Rothe et al., 2016) is a process that, in contrast, can contribute to long-term P retention in the sediment, particularly in ferruginous (anoxic, non-sulfidic) environments (Gächter and Müller, 2003). Although anoxia is commonly thought to promote $\mathrm{P}$ release from sediments and its recycling back to the photic zone of the water column, the high ferrous iron concentrations that can develop in ferruginous environments may promote the formation of iron phosphate minerals, thereby restricting $P$ recycling and bioavailability.

Vivianite is a common phosphate mineral in lacustrine systems (Vuillemin et al., 2013; Rothe et al., 2015). It regularly occurs in organic-rich sediments, often in close association with macroscopic organic remains and when production of sulfide is low (Rothe et al., 2016). Although it is common in eutrophic lakes, presumably due to high $\mathrm{P}$ concentrations, its occurrence in ferruginous, oligotrophic lakes, which may be similar to the Archean oceans, is poorly known. In such systems, high Fe concentrations should catalyze vivianite formation, yet low $\mathrm{P}$ concentrations may preclude its formation.
Besides $\mathrm{P}$ concentrations, low content and reactivity of $\mathrm{OM}$ may also narrow rates of $\mathrm{Fe}$ reduction and thereby preclude vivianite formation due to limited release of $\mathrm{Fe}^{2+}$ to pore water (Lenstra et al., 2018).

As reported from laboratory studies, vivianite nucleation is possible under relatively high concentrations of $\mathrm{Fe}^{2+}$ and orthophosphate (solubility product: $\mathrm{Ksp}=10^{-36}$ ) at $\mathrm{pH}$ between 6 and 9 (Glasauer et al., 2003; Rothe et al., 2014; Sánchez-Román et al., 2015). It thus forms as a secondary mineral product in response to iron reduction when $\mathrm{P}$ concentrations are sufficiently high (Fredrickson et al., 1998; Zachara et al., 1998; O'Loughlin et al., 2013). Despite these requirements, vivianite formation is not restricted to any specific lake trophic state or salinity range and has been shown to form under a broad range of bottom water redox conditions from freshwater to brackish environments (Egger et al., 2015; Dijkstra et al., 2016). However, high salinities and substantial burial of OM can promote microbial reduction of $\mathrm{SO}_{4}^{2-}$ and sulfide production, which tend to restrict the formation of vivianite in the sediment (Lenstra et al., 2018).

In the humid tropics, deep and intense chemical weathering of bedrock often leads to the formation of thick laterite soils residually enriched in iron (oxyhydr)oxides that promote P scavenging (Lemos et al., 2007). Erosion of these soils and subsequent delivery to lakes promotes $\mathrm{P}$ deposition and retention in lake sediments (Fagel et al., 2005; Sapota et al., 2006; Rothe et al., 2014). One such environment is the ancient Malili Lake System, Sulawesi, Indonesia (Lehmusluoto et al., 1995; Haffner et al., 2001), whose catchment is dominated by ultramafic bedrock overlain by thick lateritic soils (Golightly et al., 2010; Morlock et al., 2019). The Malili lakes are presently characterized by a dearth of $\mathrm{SO}_{4}^{2-}$ (Crowe et al., 2004; Vuillemin et al., 2016) and low biomass (Bramburger et al., 2008), likely because fluxes of iron (oxyhydr)oxides from surrounding soils scavenge $\mathrm{P}$ in the soils, rivers and lake surface waters (Crowe et al., 2008; Katsev et al., 2010; Zegeye et al., 2012). In Lake Towuti, environmental and sedimentary processes, such as weathering intensity (Russell et al., 2014; Morlock et al., 2019), lake mixing and bottom water oxygenation (Costa et al., 2015), and fluctuations in lake level and deltaic sedimentation (Vogel et al., 2015; Hasberg et al., 2019), have changed through time and altered the abundance of reactive ferric iron, and potentially $\mathrm{P}$, in the water column and sediment. However, P dynamics have not been intensively studied in this lake.

In the short term, $\mathrm{P}$ retention in lake sediments mainly depends on the oxygenation of the water column (Reed et al., 2016), with depletion of the reducible iron pool under oxygen-poor conditions resulting in the release of accumulated P from the sediment (Katsev et al., 2006). For instance, in the $600 \mathrm{~m}$ deep, permanently stratified Lake Matano (Crowe et al., 2008), microbial reduction of iron, which takes place below the modern-day oxycline, leads to partial release of adsorbed $\mathrm{P}$ into the bottom water and its accumulation over time (Crowe et al., 2008). Like Lake Matano, 
Lake Towuti, the largest of the Malili lakes, presently displays an extreme scarcity of $\mathrm{SO}_{4}^{2-}(<20 \mu \mathrm{M})$, nitrate and nitrite $(<5 \mu \mathrm{M})$, phosphate $\left(\mathrm{PO}_{4}^{3-}<5 \mu \mathrm{M}\right)$, and oxygen depletion below $\sim 130 \mathrm{~m}$ water depth (Vuillemin et al., 2016). Evidence for a complete overturn of the water column is absent in recent years, but sediment data indicate that periods of complete overturn and bottom water oxygenation may have occurred in the geological past (Costa et al., 2015). In an oxygenated water column, hydrous ferric oxides could reach the water-sediment interface and prevent $\mathrm{P}$ and Fe release from the sediment (Shaffer, 1986; Katsev et al., 2006). In contrast, anoxia should favor the release of $\mathrm{P}$ and Fe from surface sediments and pore waters back to the anoxic bottom water, which would fundamentally change the lake's biology. Even though the lake is presently stratified, $\mathrm{PO}_{4}^{3-}$ in the modern anoxic lake is extraordinarily low, implying a sink for $\mathrm{P}$ that is stable under anoxic non-sulfidic conditions, like vivianite. Sediment drill core data, furthermore, indicate that Lake Towuti has undergone large changes in primary productivity through time, suggesting very different $\mathrm{P}$ biogeochemical cycling in the past that was possibly linked to dynamics in sediment $\mathrm{P}$ mineralogy.

The Malili lakes, including Lake Towuti, thus represent a relevant setting in which to explore the distribution and characteristics of vivianite formed under Fe-rich and fluctuating redox conditions. From May to July 2015, the Towuti Drilling Project (TDP) recovered more than $1000 \mathrm{~m}$ of sediment drill core from three sites in Lake Towuti, including a $113 \mathrm{~m}$ long core dedicated to geomicrobiological studies at site TDP-TOW15-1A (Russell et al., 2016; Friese et al., 2017). The discovery of sedimentary beds containing large vivianite crystals in this core prompted the present study investigating the distribution and characteristics of vivianite and the modes of vivianite formation in response to environmental variability, $\mathrm{P}$ sorption processes and early diagenesis of iron phases.

\section{Methods}

\subsection{Study site and drilling operations}

Lake Towuti $\left(2.5^{\circ} \mathrm{S}, 121^{\circ} \mathrm{E}\right)$ is a $200 \mathrm{~m}$ deep lake that is part of the Malili Lake System (Fig. 1), a chain of five interconnected tectonic lakes seated in ophiolitic rocks covered with thick lateritic soils on Sulawesi, Indonesia (Lehmusluoto et al., 1995; Haffner et al., 2001). The Mahalona River, which is Lake Towuti's main inflow to the north, connects to the upstream lakes Mahalona and Matano, while the Larona River constitutes Lake Towuti's only outflow to the west (Vogel et al., 2015). Lake Towuti's water column is circumneutral ( $\mathrm{pH}=8.4$ to 7.2 ), weakly thermally stratified (i.e., 31$28^{\circ} \mathrm{C}$ ) and presently oxygen-depleted below $\sim 130 \mathrm{~m}$ depth (Nomosatryo et al., 2013). The water chemistry is dominated by $\mathrm{Mg}^{2+}$ and $\mathrm{HCO}_{3}^{-}$ions (Lehmusluoto et al., 1995; Haffner et al., 2001).

The TDP coring operations were carried out from May to July 2015 using the International Continental Scientific Drilling Program (ICDP) Deep Lakes Drilling System (Russell et al., 2016). Hole TDP-TOW15-1A (156 m water depth; hereafter TDP-1A) was drilled in May 2015 with a fluid contamination tracer used to aid geomicrobiological sampling and analysis (Friese et al., 2017). Samples were collected from cores from TDP-1A immediately upon recovery, and over 450 samples were subsequently processed in the field for analyses of pore water chemistry, cell counting and microbial fingerprinting, and organic geochemistry. Pore water was extracted on site from $5 \mathrm{~cm}$ long whole round cores $(6.6 \mathrm{~cm}$ diameter) that were cut from the core sections, immediately capped and transferred to an anaerobic chamber flushed with nitrogen to avoid oxidation during sample handling (Friese et al., 2017). Core catchers from TDP-1A were packed into gas-tight aluminum foil bags flushed with nitrogen gas and heat-sealed to keep them under anoxic conditions until mineral extraction. In January 2016, the unsampled remainders of the cores from TDP-1A were split and scanned at the Limnological Research Center, Lacustrine Core Facility (LacCore), University of Minnesota, described macroscopically and microscopically to determine their stratigraphy and composition (Russell et al., 2016) and then subsampled. Minerals from core catcher sediments were extracted after 3 months of storage, and macroscopically visible vivianite crystals were handpicked from split TDP-1A cores after 8 months of storage. Except where otherwise noted, all our samples and measurements come primarily from hole TDP-1A.

\subsection{Total organic carbon and reactive and total iron}

Sediment from core catchers from TDP-1A was used to quantify total organic carbon (TOC). Sediment samples were freeze-dried prior to analysis. Carbonate minerals were removed by treating the samples with $20 \mathrm{~mL}$ of $5 \% \mathrm{HCl}$ at $50{ }^{\circ} \mathrm{C}$ for $24 \mathrm{~h}$ (Golubev et al., 2009). Following treatment, samples were repeatedly rinsed with deionized water to reach neutral $\mathrm{pH}$, centrifuged to discard water and freeze-dried. We tested this treatment using $200 \mathrm{mg}$ of technical grade siderite $\left(\mathrm{FeCO}_{3}\right)$ to evaluate dissolution. Results showed that $85 \%$ of the siderite is efficiently dissolved within the first $2 \mathrm{~h}$ of treatment and that $95 \%$ to $100 \%$ is dissolved after $24 \mathrm{~h}$ (Supplement Fig. S1). About 8 to $10 \mathrm{mg}$ of homogenized decarbonated samples were measured using an elemental analyzer (EuroVector, EuroEA). Combustion was done in an excess of oxygen at $1040^{\circ} \mathrm{C}$. TOC concentrations were calculated from the yield of $\mathrm{CO}_{2}$ after sample combustion in the elemental analyzer. Analytical precision of the method is $\pm 3 \%$ $(1 \sigma)$ of the yield of $\mathrm{CO}_{2}$. TOC was recalculated to the content of the whole sample and results are presented in dry mass weight $\%$ (wt \%). 


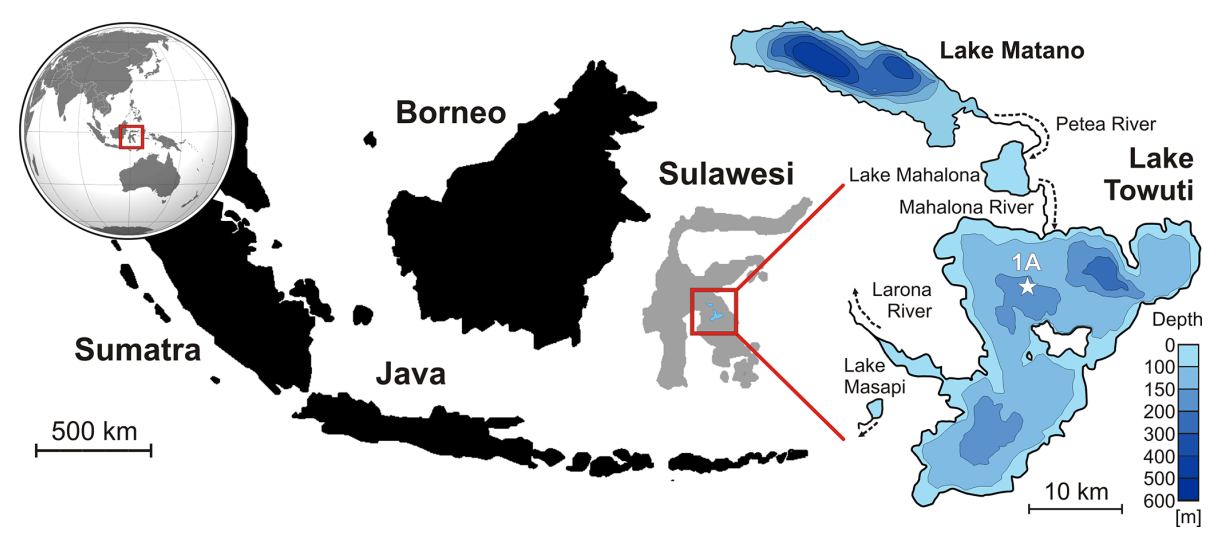

Figure 1. Location of the Malili Lake System and a bathymetric map of Lake Matano and Lake Towuti. World map displaying the location of Sulawesi (inset; red square) with a close-up of the Indonesian archipelago and location of the Malili Lake System (red square in main map). On the right is a bathymetric map of Lake Matano and Lake Towuti with the position of the ICDP drilling site TDP-1A from which hydraulic piston cores were retrieved and sampled for this study.

For reactive and total $\mathrm{Fe}$ sequential extraction, we processed $200 \mathrm{mg}$ of sediment according to Poulton and Canfield (2005). The highly reactive Fe pool is defined as the sum of carbonate-associated $\mathrm{Fe}$ (acetate-extractable $\mathrm{Fe}$ ); hydrous $\mathrm{Fe}$ (oxyhydr)oxides, including ferrihydrite and lepidocrocite $(0.5 \mathrm{~N} \mathrm{HCl}$ extractable $\mathrm{Fe}$ ); ferric (oxyhydr)oxides, including hematite and goethite (dithionite extractable $\mathrm{Fe}$ ); and magnetite (oxalate extractable $\mathrm{Fe}$ ). These reagents do not extract the Fe present in pyrite (Henkel et al., 2016). The nonreactive Fe pool is defined as Fe contained in silicate minerals after removal of reactive phases (near boiling $6 \mathrm{~N} \mathrm{HCl}$ extractable Fe) (Bauer et al., 2020). Total Fe was obtained by summing up the highly reactive $\mathrm{Fe}$ pools and the nonreactive Fe contained in silicate minerals. Our protocol could dissolve $>92 \%$ of the Fe from the PACS-2 international reference standard, ensuring high Fe yield from the samples. All Fe concentration measurements were performed using a Varian AA875 Flame Atomic Absorption Spectrophotometer (Varian, Palo Alto, USA). Precision in triplicate measurements was $1.2 \%$, and our limit of detection was $1500 \mu^{-1}$ $\left(0.15 \mathrm{wt} \%\right.$ or $\left.\sim 10 \mu \mathrm{mol} \mathrm{cm} \mathrm{cm}^{-3}\right)$.

\subsection{Pore water geochemistry}

After transfer of the complete round cores to the anaerobic chamber, pore water within the upper $10 \mathrm{~m}$ was extracted using Rhizon Pore Water Samplers (Rhizosphere research products, Dolderstraat, the Netherlands), directly inserted into the soft sediment. Below $10 \mathrm{~m}$ depth, we removed the more compact sediment samples from their liner and scraped off all potentially contaminated rims with a sterile scalpel. The remaining sediment was transferred into an Integrated Ocean Drilling Program (IODP)-style titanium pore water extraction cylinder (Mannheim et al., 1966) and placed on a two-column benchtop laboratory hydraulic press (Carver Inc., Wabash, USA). Pore water from both shallow and deep sediments was filtered through a sterile $0.2 \mu \mathrm{m}$ syringe filter and collected in a glass syringe pre-flushed with nitrogen. For anion analysis, $1 \mathrm{~mL}$ of pore water was transferred to a screw neck glass vial (VWR International, USA) and stored at $4^{\circ} \mathrm{C}$ until analysis.

Dissolved ferrous and ferric iron concentrations were measured in the field via spectrophotometry (Stookey, 1970). Directly after pore water retrieval, we aliquoted $1 \mathrm{~mL}$ of pore water sample to $1.6 \mathrm{~mL}$ Rotilabo single-use cells (Carl Roth, Karlsruhe, Germany) and stabilized dissolved $\mathrm{Fe}^{2+}$ by adding $100 \mu \mathrm{L}$ of Ferrozine Iron Reagent (Sigma-Aldrich Chemie, Munich, Germany). Absorbance of the colored solution was measured at $562 \mathrm{~nm}$ with a DR 3900 spectrophotometer (Hach, Düsseldorf, Germany). To determine pore water total $\mathrm{Fe}$ concentrations, $150 \mu \mathrm{L}$ of hydroxylamine hydrochloride was added to $800 \mu \mathrm{L}$ of the previous mixture, left to react $10 \mathrm{~min}$ to reduce all dissolved $\mathrm{Fe}^{3+}$, stabilized by adding $50 \mu \mathrm{L}$ ammonium acetate, and then absorbance of the solution was measured a second time (Viollier et al., 2000). Pore water total Fe concentrations were found to be the same as $\mathrm{Fe}^{2+}$ concentrations, and thus $\mathrm{Fe}^{3+}$ is absent in pore water. Detection limit of the method is $0.25 \mu \mathrm{M}$. Concentrations of $\mathrm{PO}_{4}^{3-}$ in pore water were measured by spectrophotometry. We aliquoted $0.5 \mathrm{~mL}$ pore water to $1.5 \mathrm{~mL}$ disposable cuvettes (Brand $\mathrm{GmbH}$, Germany) and added $80 \mu \mathrm{L}$ color reagent consisting of ammonium molybdate containing ascorbic acid and antimony (Murphy and Riley, 1962). Absorbance was measured at $882 \mathrm{~nm}$ with a DR 3900 spectrophotometer (Hach, Düsseldorf, Germany). Detection limit of the method is $0.05 \mu \mathrm{M} . \mathrm{Mn}^{2+}$ concentrations were analyzed spectrophotometrically as previously published (Jones et al., 2011 and 2015), following the formaldoxime method (Brewer and Spencer, 1971). Pore water $\mathrm{Ca}^{2+}, \mathrm{Mg}^{2+}$ and $\mathrm{SO}_{4}^{2-}$ concentrations were analyzed via normal and suppressed ion chromatography, as previously described (Vuillemin et al., 2016). Based on a respective 
signal-to-noise ratio of 3 and 10, detection and quantification limits of the method calibrated on a multielement standard are 8.3 and $38.5 \mu \mathrm{M}$ for $\mathrm{Ca}^{2+}, 9.6$ and $44.6 \mu \mathrm{M}$ for $\mathrm{Mg}^{2+}$, and 2.0 and $8.4 \mu \mathrm{M}$ for $\mathrm{SO}_{4}^{2-}$. All samples were measured in triplicates, with reproducibility better than $5 \%$.

The $\mathrm{pH}$ was measured with a portable $\mathrm{pH}$ meter (Thermo Scientific Orion, Star A321) calibrated at $\mathrm{pH} 4,7$ and 10. We homogenized $2 \mathrm{~mL}$ of sediment in $2 \mathrm{~mL}$ of deionized water and measured the supernatant after 2 min, which is the method commonly used to measure $\mathrm{pH}$ in organic-rich soil samples. We followed the published method no. 9045B from Black (1973) and calibrated our results based on the Standard Reference Material Catalog (Seward, 1986). We note, however, that direct measurements of $\mathrm{pH}$ in the sediment pore water with, for example, microsensors would provide a better indication of the in situ pH (e.g., Reimers et al., 1996). Total alkalinity was measured via colorimetric titration on samples of Rhizon-extracted and hydraulically squeezed pore water. Dissolved inorganic carbon (DIC) concentrations were calculated by solving the carbonate system using the $\mathrm{pH}$ and alkalinity profiles and borehole temperatures (Jenkins and Moore, 1977). The complete pore water dataset, inclusive of all major cations and anions (Vuillemin et al., 2019a), was used to calculate mineral saturation indices based on $\mathrm{pH}$, alkalinity, pore water concentrations and borehole temperatures, using the PHREEQC v.3 software (Parkhurst and Appelo, 2013).

\subsection{Vivianite identification and crystal separation}

The drill cores from TDP-1A remaining after field sampling of whole core rounds were split at LacCore, University of Minnesota, USA. Split core halves were imaged at a resolution of 10 pixels $\mathrm{mm}^{-1}(\sim 254 \mathrm{dpi})$ using a Geotek Geoscan-III with line scan charge-coupled device (CCD) cameras with fluorescent lights and polarizing filters to reveal core stratigraphy (Russell et al., 2016). Macroscopically visible vivianite crystals were handpicked from split TDP-1A cores from five distinct horizons located between 20 and $50 \mathrm{~m}$ sediment depth. Additional mineral separates of vivianite were obtained from core catchers. We mixed $50 \mathrm{~mL}$ of sediment with deionized water in a beaker and sonicated the slurry to homogenize and break up clay aggregates. The slurry was then separated with an initial settling time of $\sim 2$ min and removal of the supernatant. We separated the magnetic from the nonmagnetic fraction in the settled dense fraction by placing a neodymium magnet below the beaker and rinsing out the nonmagnetic mineral fraction with deionized water, followed by drying with acetone. Minerals observed under a stereo microscope (Nikon SMZ800) included siderite, vivianite, millerite (i.e., NiS) and detrital pyroxene (i.e., $\mathrm{Ca}(\mathrm{Mg}, \mathrm{Fe}) \mathrm{Si}_{2} \mathrm{O}_{6}$ ). Pyrite (i.e., $\mathrm{FeS}_{2}$ ) was not observed. Vivianite crystals, which were identified in the interval from 20 to $50 \mathrm{~m}$ sediment depth, were handpicked under the stereo microscope for further analyses.

\subsection{X-ray powder diffraction}

X-ray diffraction (XRD) patterns were obtained for one concentrated extract of powdered vivianite, as well as for six samples of freeze-dried bulk sediment from different depths (i.e., 6.3 12.4, 23.4, 52.7, 66.5 and $82.6 \mathrm{~m}$ ), using a PANalytical Empyrean X-ray diffractometer (Eindhoven, the Netherlands), operating with a theta-theta goniometer at $40 \mathrm{kV}$ and $40 \mathrm{~mA}$ and a PIXcel 3D detector. $\mathrm{CuK} \alpha$ radiation was used with a step size from 4.6 to $85^{\circ} 2 \Theta$ and a count time of $1 \mathrm{~min}$ per step. The software packages AXS DIFFRACplus EVA and AXS Topas v. 4.2 (both Bruker) were used to identify minerals and select peak references from the mineralogical database.

\subsection{Field emission scanning electron microscopy}

Isolated crystals of vivianite were mounted on $12.7 \mathrm{~mm}$ diameter aluminum stubs with double-sided conductive carbon tape. An entire vivianite crystal was also embedded in epoxy and the stub cut in axial section. An ultra-thin coating of carbon was deposited on the samples by high-vacuum sputter coating using a Leica MED 020 BAL-TEC metallizer. Imaging was carried out using an Ultra 55 Plus Schottky-type field emission scanning electron microscope. This microscope is equipped with an X-ray energy-dispersive (EDX) system and a Thermo Fisher Scientific silicon drift detector (SDD UltraDry) for elemental analysis. Operating parameters were set at an acceleration voltage of $20 \mathrm{kV}$, a working distance of $12.5 \mathrm{~mm}$ for secondary electron and backscattering electron images, a $120 \mathrm{~mm}$ wide aperture, a silicon drift detector take-off angle of $35^{\circ}$, and an acquisition time of $30 \mathrm{~s}$ at a reduced count rate and dead time as needed for point analyses. Calculation of particle chemistry was performed by applying the procedure of the Noran System 7 software based on the standard-less matrix correction method ZAF (i.e., Z, atomic number effect; A, self-absorption effect; and F, fluorescence effect) and $\phi(\rho z)$. Quantitative analyses of all detectable elements were normalized to $100 \%$ atomic weight displayed as oxides. The detection limit for EDX ranges between $0.1 \mathrm{wt} \%$ and $1 \mathrm{wt} \%$.

\subsection{Transmission electron microscopy}

Preparation of electron-transparent vivianite samples was done with a FEI FIB200TEM focused ion beam (FIB) device. A transmission electron microscopy (TEM)-ready foil with final dimensions of $15 \mu \mathrm{M} \times 10 \mu \mathrm{M} \times 0.1 \mu \mathrm{M}$ was cut directly from the carbon-coated polished section using a gallium ion beam under high-vacuum conditions and placed on a carbon film on top of a copper grid. Carbon-coating to prevent charging of the TEM sample was not applied (Wirth, 2009). The FIB-cut TEM foil was surveyed and analyzed using a FEI Tecnai $G^{2}$ F20 X-Twin transmission electron microscope. The microscope is equipped with an EDAX ultra-thin win- 
dow EDX system, a Fishione high-angle annular dark field (HAADF) detector and a Gatan imaging filter. Operating conditions were set to an acceleration voltage of $200 \mathrm{kV}$, using normal imaging mode for bright field and dark field imaging and scanning transmission electron microscopy mode for HAADF imaging and analytical electron microscopy. All HAADF images were acquired with a camera length of either 75 or $330 \mathrm{~mm}$. The short camera length $(75 \mathrm{~mm})$ allows us to image $Z$ contrast, whereas the long camera length $(330 \mathrm{~mm})$ allows for simultaneous imaging of $Z$ contrast and diffraction contrast. Bright field images were digitally recorded. Semiquantitative compositional spectra on both crystalline and amorphous phases were obtained from EDX spectrometer within 60-120 s live time. Beam size in scanning transmission electron mode was 1 to $2 \mathrm{~nm}$ and applied across the preselected areas during data acquisition. Structural information on crystalline phases was obtained from selected area electron diffraction patterns recorded on image plates for high precision.

\subsection{Fe isotope analysis}

After density separation, vivianite crystals were handpicked under the stereo microscope and the isolated crystals processed for Fe isotope analyses at the HELGES lab, GFZ Potsdam (von Blanckenburg et al., 2016); however, the presence of some minor inclusions of siderite, silicates and oxides within vivianite crystals could not be ruled out. To avoid dissolution of silicates and oxides, about $5 \mathrm{mg}$ of sample powder was leached with $2 \mathrm{M} \mathrm{HNO}_{3}$ for $24 \mathrm{~h}$ at room temperature (von Blanckenburg et al., 2008). Complete dissolution of vivianite and a few solid residual particles were observed. After centrifugation, supernatants (dissolved vivianite and trace siderite) were evaporated in perfluoroalkoxy alkane (PFA) vials on a hot plate at $110^{\circ} \mathrm{C}$, then heated in closed vials at $150{ }^{\circ} \mathrm{C}$ with $\mathrm{H}_{2} \mathrm{O}_{2}-\mathrm{HNO}_{3}$ and aqua regia to remove all OM. Procedure blanks and reference materials (USGS COQ1 carbonatite rock, BHVO-2 basalt rock, HanFe pure Fe solution) were processed along with samples for quality control. After evaporation, samples were redissolved in $6 \mathrm{M} \mathrm{HCl}$ and an aliquot of $\sim 100 \mu \mathrm{g}$ Fe was passed through chromatographic columns (DOWEX AG-X8 resin) to purify Fe from other matrix elements (Schoenberg and von Blanckenburg, 2005). Purity and quantitative recovery of Fe was verified by inductively coupled plasma-optical emission spectrometry (ICP-OES, Varian 720ES) and found to be better than $98 \%$. $\mathrm{Cr}$ and $\mathrm{Ni}$ were efficiently separated from $\mathrm{Fe}$, thus eliminating spectral interferences of ${ }^{54} \mathrm{Cr}$ on ${ }^{54} \mathrm{Fe}$ and ${ }^{58} \mathrm{Ni}$ on ${ }^{58} \mathrm{Fe}$. Blanks of all procedures were measured by quadrupole ICPMS (Thermo iCAP-Qc) and contained $<10 \mathrm{ng} \mathrm{Fe}$, thus contributing to $<0.01 \%$ of processed Fe samples $(\sim 100 \mu \mathrm{g})$, and they are therefore considered negligible.

Prior to isotope analysis, samples were dissolved in $0.3 \mathrm{MHNO}_{3}$ and diluted to $\sim 5 \mu \mathrm{g} \mathrm{mL}^{-1} \mathrm{Fe}$ to match the concentration of the bracketing standard (IRMM-014) within $10 \%$. Fe isotopic analyses were performed using a Thermo Scientific Neptune multi-collector inductively coupled plasma mass spectrometer (MC-ICP-MS) equipped with a Neptune Plus Jet Interface pump and a quartz-glass spray chamber (double-pass cyclone Scott-type, Thermo stable introduction system, SIS) with a $100 \mu \mathrm{L} \mathrm{min}^{-1}$ selfaspirating PFA nebulizer for sample introduction. Analyses were run in high mass resolution mode (mass-resolving power $\mathrm{m} / \Delta \mathrm{m}(5 \%, 95 \%) \sim 9000)$ to resolve all $\mathrm{Fe}$ isotopes from polyatomic interferences (i.e., $\mathrm{ArO}, \mathrm{ArOH}$ and $\mathrm{ArN}$ ). Potential interferences of ${ }^{54} \mathrm{Cr}$ on ${ }^{54} \mathrm{Fe}$ and ${ }^{58} \mathrm{Ni}$ on ${ }^{58} \mathrm{Fe}$ were monitored at masses ${ }^{52} \mathrm{Cr}$ and ${ }^{60} \mathrm{Ni}$. The sample standard bracketing method (using IRMM-014 as bracketing standard) was used to correct for instrumental mass bias (Schoenberg and von Blanckenburg, 2005). Isotope ratios $\left({ }^{56} \mathrm{Fe} /{ }^{54} \mathrm{Fe}\right.$ and ${ }^{57} \mathrm{Fe} /{ }^{54} \mathrm{Fe}$ ) are reported in the $\delta$ notation in per mil $(\% o)$ relative to the international reference material IRMM014 (e.g., $\delta^{56} \mathrm{Fe}=\left({ }^{56} \mathrm{Fe} /{ }^{54} \mathrm{Fe}_{\text {sample }} /{ }^{56} \mathrm{Fe} /{ }^{54} \mathrm{Fe}_{\text {IRMM-04 }}-1\right)$ $\times 1000$ ). Measurements were repeated between two and eight times in two independent analytical sessions. Results of $\delta^{57} \mathrm{Fe}$ and $\delta^{56} \mathrm{Fe}$ all follow mass-dependent isotope fractionation, and therefore results are only discussed in terms of $\delta^{56} \mathrm{Fe}$ with an uncertainty of the method estimated to be $\pm 0.05 \% \circ(2 \sigma)$ in $\delta^{56} \mathrm{Fe}$, as verified during this study by repeated analyses of reference materials and comparison to published reference values (Table S1 in the Supplement).

\section{Results}

\subsection{Lithology and core scanning images}

The lithology of TDP site $1 \mathrm{~A}$ is displayed from 0 to $100 \mathrm{~m}$ depth (Fig. 2a), ending at the boundary between the predominantly fine-grained lacustrine Unit 1 and the more coarsegrained fluvio-lacustrine Unit 2 (Russell et al., 2016). The upper $100 \mathrm{~m}$ of sediment consists largely of alternating dark reddish-grey and brown to dark green and grey lacustrine clay beds (Fig. 2a-b). Turbidites are relatively rare but more common below $50 \mathrm{~m}$ and above $25 \mathrm{~m}$ depth, and two $\sim 5 \mathrm{~m}$ beds of diatom ooze occur at $\sim 35$ and $45 \mathrm{~m}$ depth. We also observed tephras throughout Unit 1 . We focus on five intervals containing vivianites between 20 and $50 \mathrm{~m}$ depth, where sediment types include both red and green clays, diatomaceous oozes and several large tephras (Fig. 2a). Vivianites are mostly found in green clays, often overlain by siderite-rich red clays and, occasionally, turbidites (Fig. S3). Diatomaceous oozes are devoid of vivianite and siderite. A more detailed description of the full stratigraphy is published elsewhere (Russell et al., 2016).

\subsection{Total organic carbon and reactive and total iron}

Over the upper $100 \mathrm{~m}$ of the sediment sequence at site TDP-1A, TOC values (Fig. 2a) vary between $\sim 6 \mathrm{wt} \%$ and $0.2 \mathrm{wt} \%$. The upper $20 \mathrm{~m}$ of sediments display concentra- 


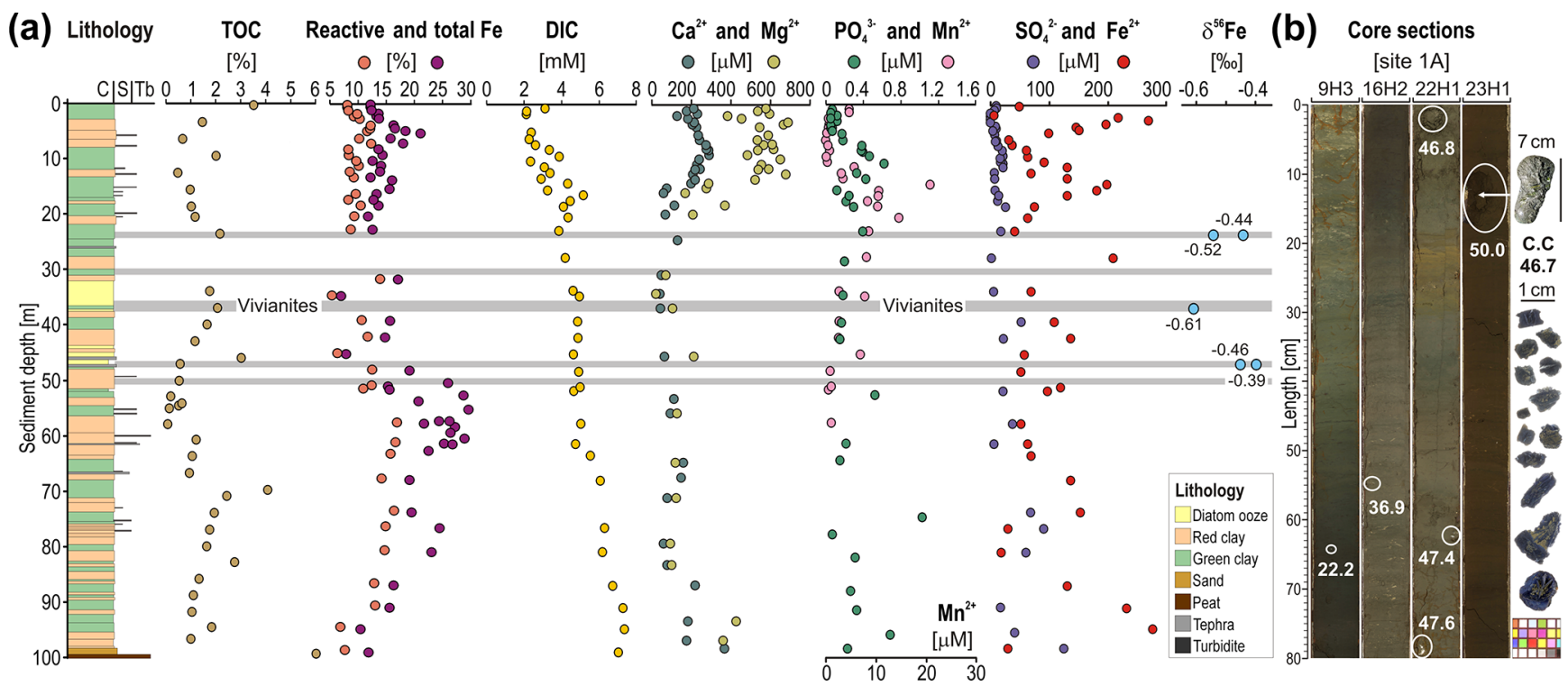

Figure 2. Stratigraphy of composite site TDP-1A: multiple profiles established on sediment core subsamples and core section images. (a) Stratigraphy of composite site TDP-1 (following Russell et al., 2016) and corresponding grain sizes (C: clay; S: silt; Tb: turbidite); total organic carbon (TOC) and reactive and total iron (weight \%) in bulk sediment; dissolved inorganic carbon (DIC) (mM), calcium, magnesium, phosphate, manganese, sulfate, and ferrous iron concentrations $(\mu \mathrm{M})$ measured in pore water; and $\delta^{56} \mathrm{Fe}$ isotopic compositions of vivianite crystals. (b) Images of core sections from which vivianite crystals were handpicked. Crystals on the far right were extracted from core catchers.

tions fluctuating between $3.5 \mathrm{wt} \%$ and $0.5 \mathrm{wt} \%$ with an overall decrease with depth. In the vivianite-bearing interval (20$50 \mathrm{~m}$ ), values reach maxima of $\sim 3 \mathrm{wt} \%$ in the diatomaceous oozes. In the lowermost part of the record, TOC gradually increases from $1.0 \mathrm{wt} \%$ at $50 \mathrm{~m}$ depth to $4.0 \mathrm{wt} \%$ at $80 \mathrm{~m}$ depth, with the highest values $(\sim 6 \%)$ at the bottom of the core just above the peat layer.

Reactive Fe concentrations vary from $7 \mathrm{wt} \%$ to $12 \mathrm{wt} \%$ within the upper $20 \mathrm{~m}$ of the sediment record, fluctuate between $5 \mathrm{wt} \%$ and $15 \mathrm{wt} \%$ with the vivianite-bearing interval, and remain relatively constant around $15 \mathrm{wt} \%$ below. Total Fe concentrations generally fluctuate between $15 \mathrm{wt} \%$ and $20 \mathrm{wt} \%$ in Unit 1, with the exception of the interval between 50 and $80 \mathrm{~m}$ depth, where values occasionally reach $25 \mathrm{wt} \%$ to $30 \mathrm{wt} \%$. Some of these high values occur within turbidite beds. The lowest values $(\sim 7 \mathrm{wt} \%)$ are found within the diatomaceous oozes at 35 and $45 \mathrm{~m}$ depth and just above a peat layer at $\sim 100 \mathrm{~m}$ depth.

\subsection{Pore water geochemistry and modeled saturation indices}

In the upper $20 \mathrm{~m}$ of sediment, pore water DIC concentrations increase gradually from 2 to $6 \mathrm{mM}$ with depth. Values drop to $4 \mathrm{mM}$ at $20 \mathrm{~m}$ depth and then increase gradually from 4 to $7 \mathrm{mM}$ down to $100 \mathrm{~m}$ depth. Profiles for pore water $\mathrm{Ca}^{2+}$ and $\mathrm{Mg}^{2+}$ concentrations display similar trends, with maximum values observed within the upper $15 \mathrm{~m}$ of sediment followed by a drop of their respective values from 200 and
$600 \mu \mathrm{M}$ to close to zero. Pore water $\mathrm{PO}_{4}^{3-}$ concentrations in the upper $10 \mathrm{~m}$ of sediments increase gradually from 0 to $0.62 \mu \mathrm{M}$ with depth. Between 20 and $50 \mathrm{~m}$ depth, values remain low $(0.15$ to $0.20 \mu \mathrm{M})$. Concentrations of pore water $\mathrm{Mn}^{2+}$ are initially $\sim 5 \mu \mathrm{M}$ in the upper meter of the sediment, minimal in the next $10 \mathrm{~m}$ of sediment and then increase to $20 \mu \mathrm{M}$ down to $20 \mathrm{~m}$ depth. With the vivianite bearinginterval, $\mathrm{Mn}^{2+}$ concentrations gradually decrease to a minimum at $50 \mathrm{~m}$ depth. Concentrations of pore water $\mathrm{SO}_{4}^{2-}$ were often close to our quantification limit $(8.4 \mu \mathrm{M})$, with concentrations between 10 and $25 \mu \mathrm{M}$. Slightly increased concentrations are observed around $75 \mathrm{~m}$ depth. Concentrations of pore water $\mathrm{Fe}^{2+}$ are highly variable throughout the sedimentary sequence $(17-278 \mu \mathrm{M})$. Some of the intervals with the highest dissolved $\mathrm{Fe}^{2+}$ values are found in the uppermost part of the record (1-6m), from 15 to $20 \mathrm{~m}$ depth just above the vivianite interval and in the lowermost section of the core (90-100 m). Below $50 \mathrm{~m}$ depth, both $\mathrm{Fe}^{2+}$ and $\mathrm{PO}_{4}^{3-}$ values generally peak in the vicinity of turbidite layers.

Geochemical modeling of the pore water chemistry indicates supersaturation with respect to siderite at $5 \mathrm{~m}$ depth (1.29) and over the entire lower sediment sequence (Table 1). In contrast, vivianite is undersaturated in pore water at $5 \mathrm{~m}$ $(-0.45)$ and reaches close to but remains below saturation $(-0.04)$ in sediment at $10 \mathrm{~m}$ depth. Talc-serpentine is supersaturated in shallow sediment and becomes undersaturated with depth, whereas quartz is stable under in situ conditions. XRD spectra further support the presence and stabil- 
Table 1. Modeled saturation indices based on $\mathrm{pH}$, alkalinity, pore water concentrations of major ions and borehole temperatures. Siderite appears to be oversaturated throughout the sedimentary sequence, whereas vivianite remains close to but slightly below saturation with sediment depth.

\begin{tabular}{lrlr}
\hline 5 m depth & Saturation & 10 m depth & Saturation \\
\hline Talc-serpentine & 1.43 & Siderite & 1.00 \\
Siderite & 1.29 & Quartz & 0.71 \\
Quartz & 0.71 & Vivianite & -0.04 \\
Vivianite & -0.45 & Talc-serpentine & -0.31 \\
Calcite & -0.68 & Calcite & -0.83 \\
Dolomite & -0.77 & Aragonite & -0.97 \\
Aragonite & -0.82 & Dolomite & -1.27 \\
\hline
\end{tabular}

ity of specific phases, such as siderite, quartz and serpentine (Fig. S2).

\subsection{Iron isotopes}

Iron isotopes measured on single vivianite crystals (Fig. 2a) display $\delta^{56} \mathrm{Fe}$ values of $-0.52 \%$ and $-0.44 \%$ at $23 \mathrm{~m}$ depth, $-0.61 \% o$ at $36 \mathrm{~m}$ depth, and $-0.39 \%$ and $-0.46 \%$ at $46 \mathrm{~m}$ depth (all $\pm 0.05 \%$ o, $2 \sigma$ ). We observe the most negative $\delta^{56} \mathrm{Fe}$ values in a specimen from the middle of the vivianitebearing interval. The iron incorporated in the measured vivianite crystals is isotopically lighter in comparison to the global bulk igneous rock reservoir $\left(\delta^{56} \mathrm{Fe}=+0.1 \pm 0.1 \%\right.$, e.g., Dauphas et al., 2017, and references therein), which is the value expected for the ultramafic igneous rocks in Lake Towuti's catchment. To the best of our knowledge, there are no existing data on vivianite $\delta^{56} \mathrm{Fe}$ in the literature that would allow comparison. As such, Fe isotope fractionation factors remain unknown for vivianite formation. However, previous studies indicate that during $\mathrm{Fe}$ redox reactions, the $\mathrm{Fe}^{2+}$ bearing phases generally become enriched in the lighter $\mathrm{Fe}$ isotopes compared to $\mathrm{Fe}^{3+}$-bearing phases (e.g., Dauphas et al., 2017). Given that vivianite is a $\mathrm{Fe}^{2+}$-bearing mineral phase, the isotopically light $\delta^{56} \mathrm{Fe}$ values we measured in vivianites from Lake Towuti are consistent with the direction of fractionation occurring during $\mathrm{Fe}^{3+}$ reduction. However, dissolution of precursory ferrous phases could also be the source of the $\mathrm{Fe}^{2+}$ incorporated in vivianite crystals.

\subsection{Vivianite detection, SEM imaging and EDX analysis}

The XRD pattern of our powdered vivianite extract confirms identification of this mineral, with an excellent match to reference peaks of one synthetic vivianite from the mineral database (Fig. 3c). Larger vivianite concretions were not observed upon inspection of split core surfaces. Vivianite was also not detected in XRD patterns of bulk sediment at six different depths. Siderite, quartz (i.e., $\mathrm{SiO}_{2}$ ) and serpentine (i.e., lizardite: $\mathrm{Mg}_{3} \mathrm{Si}_{2} \mathrm{O}_{5}(\mathrm{OH})_{4}$ ) were the main minerals clearly identified based on reference peaks in these six samples, whereas vivianite was below the XRD detection limit of $1 \%$ (Fig. S2).

Scanning electron microscopy (SEM) images of single vivianite crystals (Fig. 3a) show that the habit varies from tabular crystals at $23 \mathrm{~m}$ depth to rosette at $36 \mathrm{~m}$ depth, with the addition of blades and overall growth at $46 \mathrm{~m}$ depth, and the largest crystal $(>7 \mathrm{~cm})$ being found at $50 \mathrm{~m}$ depth. EDX points of analysis indicate partial substitution of $\mathrm{Fe}^{2+}$ by $\mathrm{Mn}^{2+}$ in the structure of vivianite crystals from 23 and $36 \mathrm{~m}$ depth (up to $\sim 17 \% \mathrm{Fe}$ substitution), resulting in their overall "manganoan" composition (Fig. 3b). Such compositions have been previously reported from both freshwater and marine sediments, although these had variable Mn concentrations (Fagel et al., 2005; Dijkstra et al., 2016). High Fe content outside the stoichiometric range of vivianite indicates the presence of residual oxides within the crystals. SEM images with locations of all EDX points of analysis are available in the Supplement (Fig. S4).

\subsection{EDX elemental mapping, TEM imaging}

SEM images of the vivianite thin section in backscattering electron mode reveal a central tabular crystal and imply growth of subsequent blades with preferential orientation directed towards the sediment surface (Fig. 4a). Close-ups also reveal the presence of mineral inclusions entrapped within the central tabular blade and the upper side of the vivianite (Fig. 4a), namely siderite (1), millerite (2) and goethite (3). Siderite appears in the form of aggregated nanocrystals, millerite in a micro-acicular habit-forming radiating aggregates and goethite in irregular sheets, whose jagged edges and dissolution features likely indicate a detrital origin and potentially partial sedimentary dissolution from iron reduction. EDX elemental mapping (Fig. 4b) and individual analyses (Fig. 4c) confirm the composition and identity of these inclusions. Increased intensities of $\mathrm{Fe}$ and $\mathrm{Mn}$ correspond to goethite, increasing $\mathrm{S}$ and $\mathrm{Ni}$ correspond to millerite, and increases in $\mathrm{Si}$ and $\mathrm{Al}$ indicate the presence of phyllosilicates inside and between vivianite blades. Ternary diagrams for individual EDX analyses show that millerite incorporates traces of iron, whereas traces of $\mathrm{Mn}$ in iron oxides indicates that it is goethite rather than hematite in which Fe substitution by Mn is limited (Singh et al., 2000).

Scanning TEM imaging of $Z$ contrast and diffraction contrast (i.e., $330 \mathrm{~mm}$ ) show that the vivianite sample from $46.8 \mathrm{~m}$ depth has a denser structure than the one from $36.7 \mathrm{~m}$ depth. Close-up images (Fig. 5) reveal the presence of iron oxides (Fig. 5a), illite clays (Fig. 5b) and detrital pyroxene (Fig. 5c), as confirmed by their EDX analyses, which show that vivianite incorporates phases of detrital origin. Fractures in the crystal from $36.7 \mathrm{~m}$ depth could be due to its partial oxidation and dehydration (Hanzel et al., 1990) or due to immaturity relative to the sample from $46.8 \mathrm{~m}$ depth. Finally, the high-resolution electron diffraction pattern of the deepest 

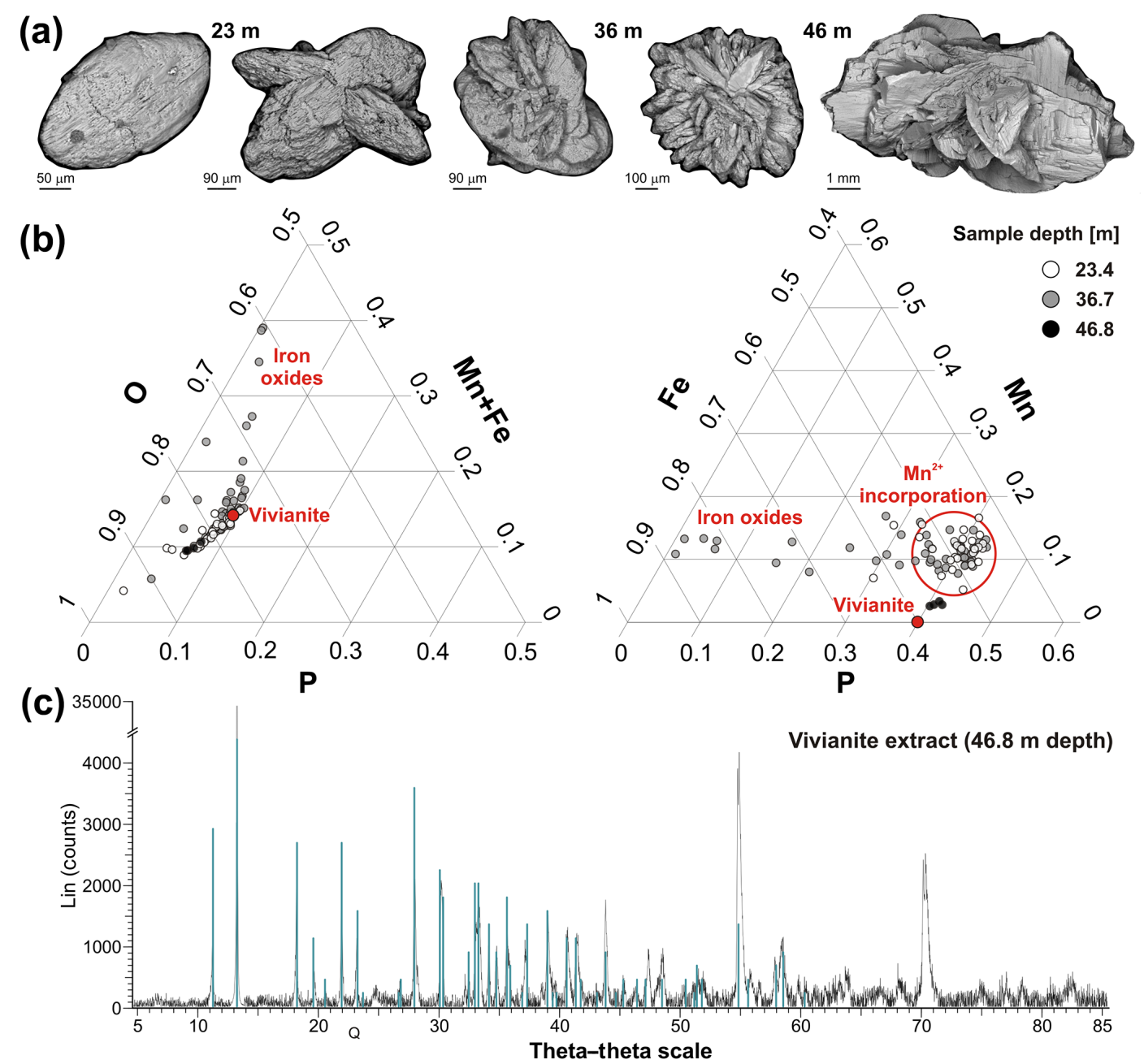

Syn. vivianite (00-030-0662) $\mathrm{Fe}_{3}\left(\mathrm{PO}_{4}\right)_{2} \cdot 8 \mathrm{H}_{2} \mathrm{O}$, Monoclinic: $\mathrm{a}=10.034, \mathrm{~b}=13.449, \mathrm{c}=4.707, \alpha=90.00, \beta=102.65, \gamma=90.00$

Figure 3. SEM images of vivianite crystals: ternary diagrams of EDX punctual analyses and XRD spectrum. (a) SEM images show that vivianite crystals grow from a tabular habit to rosette. (b) EDX elemental analyses (i.e., O, P, Fe, Mn) of vivianite crystals standardized to $100 \%$ for each ternary diagram. Results indicate incorporation of manganese in the vivianites with the presence of detrital iron oxides. The deepest samples plot closer to stoichiometric vivianite (red dot). (c) XRD spectrum of pure vivianite extract from $46.8 \mathrm{~m}$ depth with reference peaks of synthetic vivianite (blue bars).

(oldest) vivianite sample from $46.8 \mathrm{~m}$ depth demonstrates its well-ordered monoclinic structure (d), whereas the pattern of the one from $36.7 \mathrm{~m}$ depth is somewhat kinked.

\section{Discussion}

\subsection{Early microbial diagenesis and vivianite growth}

In aquatic systems and surface sediments, Fe chemistry influences the distribution of dissolved sulfide, the solubility of trace metals and bioavailability of $\mathrm{P}$, and thereby it controls their rates of burial (Severmann et al., 2006). The formation of vivianite in sediments often results from smallscale microbially mediated reactions (Rothe et al., 2016), such as reduction of ferric $\mathrm{Fe}$ minerals, with partial dis- solution and/or precipitation of mineral phases (Rothe et al., 2014; Egger et al., 2015; Tamuntuan et al., 2015; Dijkstra et al., 2016), alongside OM decomposition (Gächter et al., 2003; Hupfer and Lewandowski, 2008). In Fe-rich, $\mathrm{SO}_{4}^{2-}$-poor, oligotrophic settings like Lake Towuti and Lake Matano, where $\mathrm{HS}^{-}$production is minimal (Vuillemin et al., 2016), the first authigenic Fe minerals expected to form via the reduction of ferrihydrite are mixed-valence iron oxides (e.g., green rust, magnetite) instead of sulfides (Crowe et al., 2008; Zegeye et al., 2012; Vuillemin et al., 2019a). In nearby Lake Matano, lake waters contain more than $40 \mathrm{nM} \mathrm{Ni}$ and are supersaturated with respect to millerite where sulfide accumulates to low $\mu \mathrm{M}$ concentrations (Crowe et al., 2008). By analogy to Lake Matano, $\mathrm{Ni}$ would compete with $\mathrm{Fe}$ for sulfide in Lake Towuti and its sediments. Indeed, we observed 


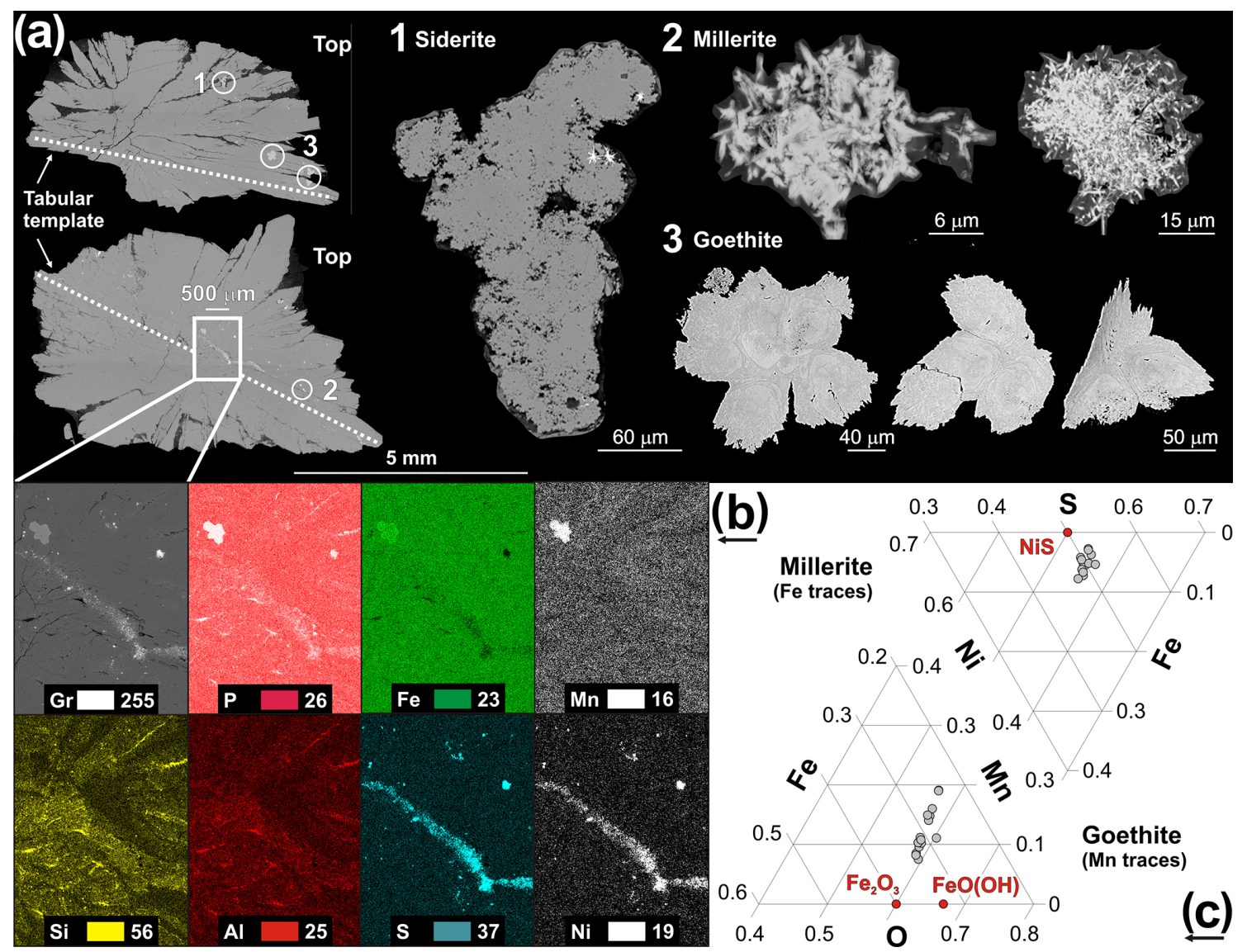

Figure 4. SEM images of vivianite crystal in axial section and close-ups of the mineral inclusions with EDX mapping and punctual analyses. (a) SEM images of an axial section of a vivianite crystal from $46.8 \mathrm{~m}$ depth, with inclusions of siderite (1), millerite (2) and goethite (3). (b) EDX elemental mapping of the framed area with relative intensity images for grey levels (Gr), phosphorus (P), iron (Fe), manganese $(\mathrm{Mn})$, silicon ( $\mathrm{Si}$ ), aluminum ( $\mathrm{Al}$ ), sulfur $(\mathrm{S})$ and nickel (Ni). (c) Ternary diagrams displaying the elemental composition of millerite and goethite as measured by punctual EDX analyses. Millerite and goethite crystals contain traces of iron and manganese, respectively.

the presence of diagenetic millerite in the sediment (Fig. 4), which forms due to the preferential reaction of $\mathrm{HS}^{-}$with dissolved $\mathrm{Ni}^{2+}$ instead of $\mathrm{Fe}^{2+}$ (Ferris et al., 1987). Since $\mathrm{SO}_{4}^{2-}$ concentrations are mostly below $50 \mu \mathrm{M}$ in the core (Fig. 2a), potential rates of sulfide production remain very low compared to the $\mathrm{Fe}$ delivery flux and $\mathrm{HS}^{-}$production has a negligible effect on $\mathrm{P}$ release from the sediment. Such low $\mathrm{SO}_{4}^{2-}$ concentrations further result in the loss of most sulfate and increased methanogenesis within the first upper meter of sediment (Vuillemin et al., 2018). As a result, processes of OM remineralization are predominantly driven by fermentation and methanogenesis (Friese et al., 2018) and DIC steadily increases with depth (Fig. 2a). Thus, in sediments such as Lake Towuti's, siderite is an expected mineral phase, and siderite is indeed abundant in some of Towuti's sediments (Ordoñez et al., 2019; Vuillemin et al., 2019a). This implies that $\mathrm{CO}_{3}^{2-}$ can compete with $\mathrm{PO}_{4}^{3-}$ for available $\mathrm{Fe}^{2+}$. Modeled mineral saturation indices confirmed this, as pore waters are saturated with respect to siderite at $5 \mathrm{~m}$ sediment depth and below. In comparison, vivianite remains close to but slightly below saturation in deep sediments (Table 1).

We observed an apparent progression in vivianite morphology from tabular to rosette with increasing depth down core (Figs. 3a and S4). Vivianite crystals develop radially and vertically during diagenesis, incorporating authigenic phases and detrital silicates within the crystal and between blades (Figs. 4, 5, S5). Authigenic phases (e.g., siderite, millerite) and detrital oxides (e.g., goethite) were trapped within these crystals (Fig. 4a). Millerite is mainly observed in the tabular template, whereas siderite and goethite are found in the upper blades of the crystal (Fig. 4a-b). The fact that authigenic siderite and millerite are observed within vivianite crystals demonstrates that vivianite forms at a later stage of diagenesis. Vivianite crystals display growth orientation toward the sediment surface, as shown by the development of successive rosettes on site (Fig. S5). In pelagic fine sediments, crystals build up to form successive spherules stacked on top of each other, reaching sizes of $\sim 4$ to $7 \mathrm{~cm}$ (Figs. S3 and S5). 

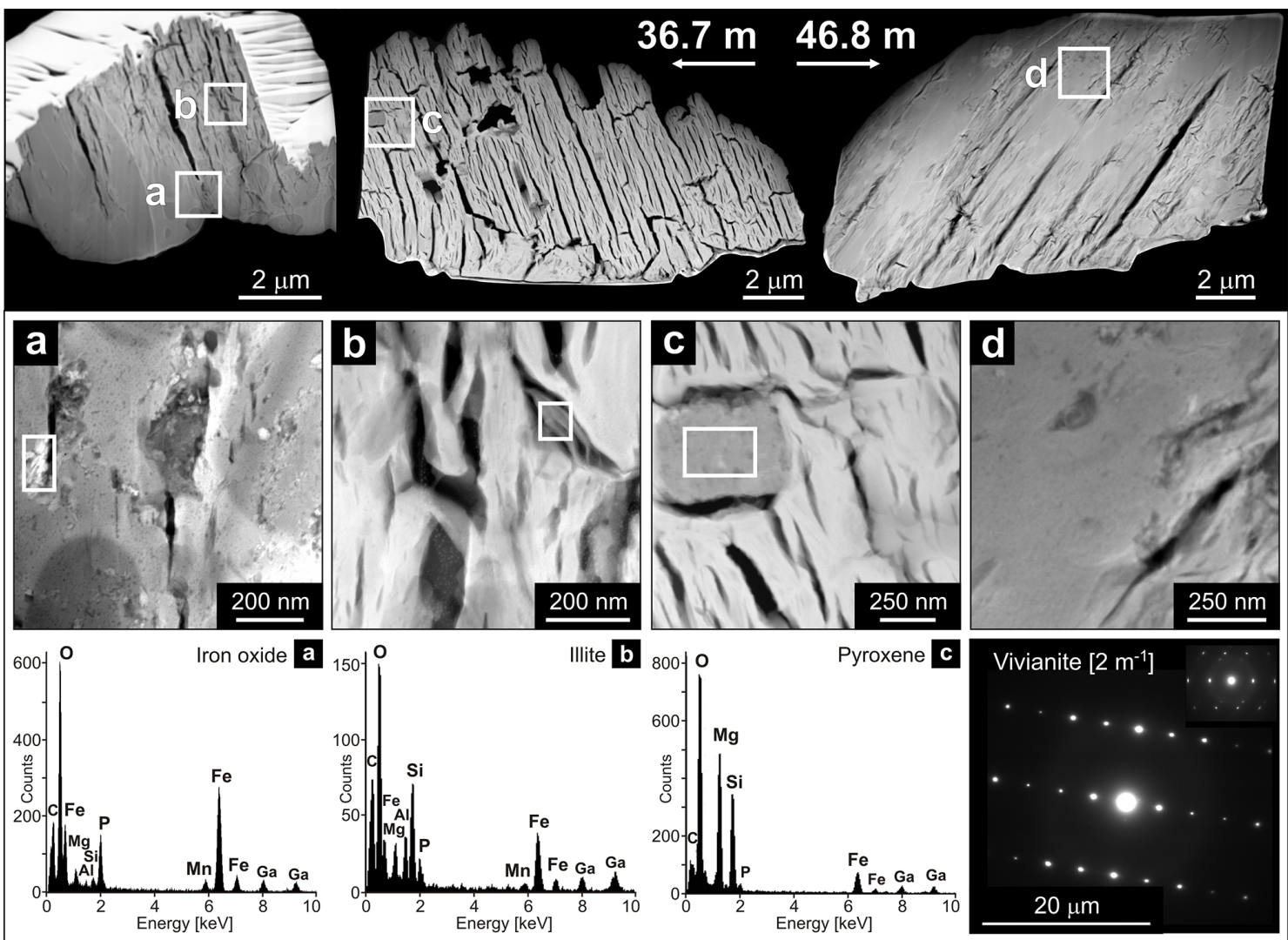

Figure 5. TEM images of vivianite crystal chunks and close-ups of detrital inclusions with their EDX analyses and vivianite electron diffraction patterns. (Top row) TEM images (distance: $330 \mathrm{~mm}$ ) of vivianite crystal chunks from 36.7 and $46.8 \mathrm{~m}$ depth, showing that the crystal structure is denser in the deeper sample. (Middle row) Close-ups of framed areas illustrating the presence of detrital inclusions within vivianite crystals, namely iron oxide (a), illite (b) and pyroxene (c). Panel (d) demonstrates the denser structure of the vivianite crystal from $46.8 \mathrm{~m}$ depth. (Bottom row) EDX spectra for iron oxide (a), illite (b) and pyroxene (c). (Bottom right) The high-resolution electron diffraction pattern of the vivianites from 46.8 and $36.7 \mathrm{~m}$ depth, providing evidence for an organized and less-organized monoclinic lattice.

Concentrations of Fe oxides in Lake Towuti's sediment are high $(\sim 20 \mathrm{wt} \%)$, and iron oxides such as goethite persist in the modern sediment even under full anoxia at the water-sediment interface and below (Sheppard et al., 2019). If $\mathrm{PO}_{4}^{3-}$ could diffuse out of the sediment, the whole-lake $\mathrm{Fe}$, $\mathrm{P}$ and oxygen dynamics predict that any $\mathrm{P}$ that might escape to the photic zone from deep, anoxic settings can be buried in oxidized shallow water sediments. In the deep sediments, pore water $\mathrm{PO}_{4}^{3-}$ concentrations are constantly low in the interval where vivianite crystals are observed (Fig. 2a), suggesting that vivianites could act as a $\mathrm{P}$ sink from the pore water to the sediment during diagenesis (Vuillemin et al., 2013, 2014). Dissolved $\mathrm{Fe}^{2+}$ concentrations are not particularly low and fluctuate $(40-100 \mu \mathrm{M})$, suggesting excess $\mathrm{Fe}$ relative to $\mathrm{P}$ and potentially reflecting dissolution of detrital phases (e.g., ferrihydrite, goethite, hematite) and/or precipitation of authigenic ones (e.g., magnetite, siderite, vivianite). Concentrations of DIC, which is produced during OM degradation, gradually increase with depth (Fig. 2a), suggesting that $\mathrm{OM}$ remineralization in shallow sediment is mainly driven by fermentation and methanogenesis rather than microbial Fe reduction (Vuillemin et al., 2018). In the vivianitebearing intervals, DIC concentrations remain rather constant $(4 \mathrm{mM})$. An explanation for this is that once $\mathrm{SO}_{4}^{2-}$ concentrations are depleted as a result of microbial reduction within the first meter of sediment, OM remineralization mostly occurs by $\mathrm{CO}_{2}$ reduction and methanogenesis (Friese et al., 2018). The onset of autotrophic methanogenesis is expected to reduce DIC activity in pore water. Moreover, $\mathrm{Ca}^{2+}$ and $\mathrm{Mg}^{2+}$ concentrations in pore water, which are predicted to control the solubility of $\mathrm{PO}_{4}^{3-}$ in ferruginous systems (Jones et al., 2015), drop around these depths as divalent cations can precipitate during siderite formation (Vuillemin et al., 2019a), suggesting that $\mathrm{PO}_{4}^{3-}$ can then outcompete $\mathrm{CO}_{3}^{2-}$ for available $\mathrm{Fe}^{2+}$ and thereby saturate pore water with respect to vivianite (Table 1) Vivianite formation is indeed reported to occur under methanogenic conditions, often initiating below the sulfate-methane transition zone (Reed et al., 2011; Dijkstra et al., 2016), presently located within the upper meter of sediment (Vuillemin et al., 2018). Since pore waters are sat- 
urated with respect to siderite at $10 \mathrm{~m}$ depth, it is likely that the initial formation of vivianite occurs in parallel with the precipitation of siderite. Inclusions of millerite and siderite within vivianite crystals (Fig. 4) provide additional lines of evidence for microbial processes of pore $\mathrm{Fe}^{3+}$ and $\mathrm{SO}_{4}^{2-}$ reduction and DIC production prior to vivianite formation. The saturation indices modeled for vivianite (Table 1) and downcore profiles of $\mathrm{Mn}^{2+}$ and $\mathrm{PO}_{4}^{3-}$ concentrations allow us to infer a depth in the sediment at which pore waters initially reached saturation with respect to vivianite (ca. $20 \mathrm{~m}$ depth). Such a relationship between dissolved $\mathrm{Mn}^{2+}$ and $\mathrm{PO}_{4}^{3-}$ is also consistent with EDX punctual analyses of vivianite crystals that show $\mathrm{Mn}^{2+}$ incorporation at an early stage (Figs. 3b, S4).

However, the fact that dissolved $\mathrm{PO}_{4}^{3-}, \mathrm{Mn}^{2+}, \mathrm{Fe}^{2+}$ and DIC vary independently also implies a decoupling in their production and consumption rates (e.g., through mineral formation and microbial metabolic consumption), such that they are not simply linked through steady-state OM respiration coupled to Fe reduction.

\subsection{Past lacustrine conditions promoting vivianite formation during burial}

In sulfur-poor, ferruginous settings, vivianite, siderite and magnetite can be formed in the sediments (Postma, 1981) depending on the local $\mathrm{pH}, \mathrm{CO}_{2}, \mathrm{PO}_{4}^{3-}$, and the amount and reactivity of ferric oxides and $\mathrm{OM}$ buried in the sediment (Fredrickson et al., 1998; Glasauer et al., 2003; O'Loughlin et al., 2013). By analogy to hydromorphic soils (Maher et al., 2003; Vodyanitskii and Shoba, 2015), redox conditions at the time of deposition and fluxes of OM and reactive ferric oxides to the sediment would select for siderite or vivianite as the main diagenetic ferrous end-members during burial. In shallow sediment cores spanning the last $\sim 60 \mathrm{kyr}$, Costa et al. (2015) suggested that elevated Fe concentrations represent time intervals of enhanced lake mixing. The alternating dark reddish-brown and lighter green and grey beds, in which vivianites were found in the deeper TDP cores (Figs. 2b, S3), also suggest variable oxygenation at the water-sediment interface in the past (Costa et al., 2015; Russell et al., 2016). Some vivianite-bearing beds appear at similar locations in multiple holes, suggesting lake-wide chemical conditions promoted diagenetic growth of vivianite in the sediment during later burial (Fig. S4). However, in other cases, vivianites appear sporadically in only one core. Below the layer in which the biggest vivianite crystal $(>7 \mathrm{~cm})$ was found $(\sim 50 \mathrm{~m}$ sediment depth), we observe increased iron concentrations $(>30 \%)$ corresponding to siderite-rich sediments and multiple turbidites ( $\sim 50$ to $60 \mathrm{~m}$; Fig. $2 \mathrm{a}$ ). Sporadic turbidites could result in discrete layers enriched in siderites, which are sometimes also linked to bottom water oxygenation, due to enhanced deposition of iron oxides and precipitation of $\mathrm{HCO}_{3}^{-}$and $\mathrm{Fe}^{2+}$ shortly after deposition (Hasberg et al., 2019; Sheppard et al., 2019). Such turbidites may also promote spradic laterally noncontiguous vivianite formation in one site (Fig. S4). For instance, a large flattopped vivianite crystal $(>4 \mathrm{~cm}$ ) capped by a turbidite shows how rapid sedimentary processes prevent further growth of this mineral (Fig. S5).

Within the vivianite-bearing interval (20-50 m depth), diatomaceous oozes signify relatively high primary productivity, and their corresponding iron concentrations are lowest, which is consistent with the absence of siderite and vivianite therein (Fig. 2a). Below and above this interval, vivianites are rarely present in the sediment, which was confirmed by smear slide analysis (Russell et al., 2016) and X-ray diffraction (Fig. S2). The substantial fossilization of diatoms, with vivianites below and above these sediments, could reflect higher $\mathrm{P}$ concentrations in the water column during this time interval compared to present-day levels, pointing either to increased $\mathrm{P}$ supply to the basin and/or a change in $\mathrm{P}$ recycling. Given the slow sedimentation rates $\left(\sim 0.2 \mathrm{~m} \mathrm{kyr}^{-1}\right)$ in the upper $10 \mathrm{~m}$ of sediments (Russell et al., 2014), it seems likely that the 20-50 m interval encompasses at least $100 \mathrm{kyr}$. During the Last Glacial Maximum (LGM), Towuti's lake level was 15 to $30 \mathrm{~m}$ lower than today, possibly resulting in endorheic conditions (Costa et al., 2015; Vogel et al., 2015). By analogy, lake levels may have been lower during preceding glacial phases, at least one of which is likely to be included in the vivianite-bearing interval. While lake shrinkage could affect algal productivity in the remaining waters (Clavero et al., 1993; Schütt, 1998; Bernal-Brooks et al., 2003; Recasens et al., 2015), lower lake levels could also promote bottom water oxygenation and burial of $\mathrm{Fe}$ oxides and thereby suppress $\mathrm{P}$ recycling. Tephras, if they bear apatite (i.e., $\mathrm{Ca}_{5}\left(\mathrm{PO}_{4}\right)_{3}$ $(\mathrm{OH})$ ) or additional $\mathrm{P}$ adsorbed onto their mineral phases, could represent an additional source of $\mathrm{P}$ to the lake (Harper et al., 1986; Nanzyo et al., 1997; Ayris and Delmelle, 2012). As $\mathrm{P}$ concentrations tend to affect algal phytoplankton productivity as a whole (Zhang and Prepas, 1996; Van der Grinten et al., 2004), high Si concentrations in the lake represent an additional factor promoting the preservation of diatoms over cyanobacteria during sinking and burial. Finally, sediment-starved conditions would also limit P scavenging in the water column. In contrast, increased delivery of detrital iron (oxyhydr)oxides precipitates $P$ to the sediment and initially forms sideritic beds, whereas vivianite formation initiates under slow kinetics deeper in the sediment than for siderite (Postma, 1981), as demonstrated by the incorporation of siderite, millerite and clay minerals in the vivianites (Figs. 4 and 5).

\subsection{The $\delta^{56} \mathrm{Fe}$ compositions of vivianites and implications for the Archean rock record}

Previous Fe isotope studies of lakes identified either partial oxidation of $\mathrm{Fe}^{2+}$ in the water column or microbial iron reduction below the sediment-water interface as the main drivers for Fe mineralization and transformation pathways 
and isotope fractionation (Teutsch et al., 2009; Song et al., 2011; Liu et al., 2015). Depending on rates of reduction and dissolution (Brantley et al., 2001), dissimilatory microbial reduction of iron releases $\mathrm{Fe}^{2+}$ that is up to $2 \%$ lighter than the original substrates (Crosby et al., 2007; Tangalos et al., 2010), therefore iron isotopes are commonly used to trace redox processes related to microbial activity in aquatic sediments (Percak-Dennett et al., 2013; Busigny et al., 2014). During sediment early diagenesis, the preferential dissolution of isotopically light $\mathrm{Fe}^{2+}$ leaves behind an increasingly heavier residual Fe pool (Staubwasser et al., 2006), which results in the diffusive accumulation of the light isotopes in the top layer of sediments, where they can be adsorbed and incorporated into ferrous $\mathrm{Fe}$ phases. The $\delta^{56} \mathrm{Fe}$ values reported for pore water $\mathrm{Fe}^{2+}$ in lacustrine sediments range between $-2 \%$ and $-1 \%$ and become heavier with depth as authigenic phases form (Song et al., 2011; Percak-Denett et al., 2013). The $\delta^{56} \mathrm{Fe}$ values for reduced $\mathrm{Fe}$ phases formed in the sediment are highly variable and range from $-1.5 \%$ to $-0.8 \%$ for pyrite (Busigny et al., 2014), $-1.6 \%$ o to $0.3 \%$ o for siderite (Johnson et al., 2005) and $-0.1 \%$ o to $0.2 \%$ for magnetite (Percak-Denett et al., 2013).

Compared to the global bulk igneous rock reservoir $\left(\delta^{56} \mathrm{Fe}=+0.1 \pm 0.1 \% \circ\right)$ and ultramafic rocks (Dauphas et al., 2017) such as those present in Lake Towuti's catchment, the $\delta^{56} \mathrm{Fe}$ measured on whole vivianite crystals $(-0.61 \%$ o to $-0.39 \%$ ) reveals incorporation of isotopically fractionated light $\mathrm{Fe}^{2+}$ (Fig. 2a), even though traces of detrital ironbearing minerals and secondary oxides are present within vivianite crystals (Figs. 4 and 5). Towuti's Fe mineralogy from source to sink reflects complex cycling of $\mathrm{Fe}$ as iron minerals derived from catchment soils (e.g., goethite, hematite, magnetite) tend to transform into nanocrystalline Fe phases during reductive dissolution in the lake water column and sediment (Tamuntuan et al., 2015; Sheppard et al., 2019). Ferric and ferrous phases precipitating in equilibrium at the oxycline or during mixing events could be abiotically fractionated to $1 \%-2 \%$ o heavier and lighter isotope values than the remaining aqueous $\mathrm{Fe}^{2+}$ (Bullen et al., 2001; Skulan et al., 2002; Beard et al., 2010; Wu et al., 2011). After deposition, partitioning of the light $\mathrm{Fe}$ isotopes mainly transits through release to pore water (Henkel et al., 2016) implying a succession of mineral transformation and dissolution with internal diagenetic $\mathrm{Fe}$ redistribution during burial (Severmann et al., 2006; Scholz et al., 2014). For instance, mixed-valence iron oxides (e.g., green rust), which are authigenic phases that form initially under ferruginous conditions (Zegeye et al., 2012; Vuillemin et al., 2019a), can react with pore water $\mathrm{HCO}_{3}^{-}$and $\mathrm{HPO}_{4}^{2-}$, and thereby transform into either siderite or vivianite as the sediment ages (Hansen and Poulsen, 1999; Bocher et al., 2004; Refait et al., 2007; Halevy et al., 2017). Because vivianite formation initiates in the sediment, we infer that vivianite crystals acted as additional traps for the reduced $\mathrm{Fe}^{2+}$ released to pore water and that their light $\delta^{56} \mathrm{Fe}$ values are consistent with kinetic fractionation related to mi- crobial $\mathrm{Fe}$ reduction during early diagenesis, or eventually inherited from postdepositional dissolution of transient ferrous phases. In the latter case, pre-depositional processes of abiotic $\mathrm{Fe}$ fractionation related to stratified conditions will require further investigations.

Whether they relate to microbial reduction in soft ferruginous sediment or past conditions in bottom waters, biotic and abiotic processes that led to the deposition of ancient iron formations remain challenging to interpret on the basis of their Fe mineral assemblages and isotope compositions (Johnson et al., 2013; Posth et al., 2014). Estimates of concentrations of $\mathrm{P}$ in deep anoxic waters, as deduced from the Archean rock record, typically range from 40 to $120 \mu \mathrm{M}$ for Fe and 0.1 to $0.3 \mu \mathrm{M}$ for P (Holland, 2006; Konhauser et al., 2007; Jones et al., 2015), which are similar to those presently observed in the pore water of ferruginous analogue Lake Towuti (Fig. 2a). Concerning P diagenesis, it is hypothesized that $\mathrm{P}$ availability in the Archean ocean was limited by the lack of terminal electron acceptors and oxidative power used to recycle most of the OM-bound $\mathrm{P}$ rather than by scavenging by Fe minerals (Kipp and Stüeken, 2017; Michiels et al., 2017; Herschy et al., 2018). The present $\mathrm{Ca}^{2+}$ and $\mathrm{Mg}^{2+}$ concentrations in pore water exert apparent control on the precipitation of siderite and/or vivianite during early diagenesis (Vuillemin et al., 2019a), which is comparable to interpretations of ancient $\mathrm{P}$ availability in regards to hydrothermal and continental weathering of mafic rocks (Jones et al., 2015). In this context, because secondary P-bearing minerals cannot form if $\mathrm{P}$ remains bound to $\mathrm{OM}$, we suggest that the precipitation of millerite, siderite and vivianite in the sediment constitutes a likely diagenetic sequence stemming from the progressive consumption of dissolved terminal electron acceptors and evolution of pore water geochemistry, along with the related loss of oxidative power during OM remineralization, with consequent long-term $\mathrm{P}$ sequestration.

\section{Conclusions}

Non-steady-state conditions likely promoted the sporadic formation of diagenetic vivianites within otherwise sideriterich sediments during a prolonged interval of ferruginous Lake Towuti's history. Although the source of $\mathrm{P}$ is not well constrained, its inputs stimulated diatom productivity and sporadic vivianite formation during diagenesis. Inclusions of millerite, siderite and partially dissolved goethite within vivianite crystals support the assumption that microbial $\mathrm{Fe}^{3+}$ and $\mathrm{SO}_{4}^{2-}$ reduction took place prior to vivianite formation. With depth and over time, vivianite crystals grew and changed from tabular to rosette morphologies, including surrounding clays. The corresponding $\delta^{56} \mathrm{Fe}$ compositions confirmed that these crystals incorporated microbially fractionated light $\mathrm{Fe}^{2+}$ during diagenesis. While these light isotopic signatures may also point to pre-depositional $\mathrm{Fe}$ fractionation related to lake stratification and dissolution of transient fer- 
rous phases, the precipitation of millerite, siderite and vivianite along burial in ferruginous sediment is consistent with the progressive consumption of dissolved terminal electron acceptors and related loss of oxidative power during OM remineralization, which results in long-term sequestration of $\mathrm{P}$ as vivianite. Thus, identification of these diagenetic phases could be used to interpret postdepositional processes of microbial reduction and thereby help constrain early diagenesis time-wise.

Data availability. Present scientific data are archived and publicly available from the PANGAEA ${ }^{\circledR}$ Data Publisher for Earth and Environmental Science (Vuillemin et al., 2019b).

Supplement. The supplement related to this article is available online at: https://doi.org/10.5194/bg-17-1955-2020-supplement.

Team list. Martin Melles (Institute for Geology and Mineralogy, University of Cologne, Zülpicher Str. 49a/b, 50674 Cologne, Germany), Silvia Fajar (Faculty of Mining and Petroleum Engineering, Institut Teknologi Bandung, Jalan Ganesa 10, Bandung, 50132, Indonesia), Abdul Hafidz (Faculty of Mining and Petroleum Engineering, Institut Teknologi Bandung, Jalan Ganesa 10, Bandung, 50132, Indonesia), Douglas Haffner (Great Lakes Institute for Environmental Research, University of Windsor, Windsor, Ontario, N9B 3P4, Canada), Ascelina Hasberg (Institute for Geology and Mineralogy, University of Cologne, Zülpicher Str. 49a/b, 50674 Cologne, Germany), Sarah Ivory (Department of Earth, Environmental, and Planetary Sciences, Brown University, 324 Brook St., Providence, RI 02912, USA), Christopher Kelly (Department of Earth, Environmental, and Planetary Sciences, Brown University, 324 Brook St., Providence, RI 02912, USA), John King (Graduate School of Oceanography, University of Rhode Island, Narragansett, RI 02882, USA), Kartika Kirana (Faculty of Mining and Petroleum Engineering, Institut Teknologi Bandung, Jalan Ganesa 10, Bandung, 50132, Indonesia), Marina Morlock (Institute of Geological Science \& Oeschger Center for Climate Change Research, University of Bern, Baltzerstrasse 1+3, 3012 Bern, Switzerland), Anders Noren (LacCore, Department of Earth Science, University of Minnesota, Minneapolis, MN 55455, USA), Ryan O'Grady (LacCore, Department of Earth Science, University of Minnesota, Minneapolis, MN 55455, USA), Janelle Stevenson (School of Culture, History and Language, Australia National University, Acton, ACT 2601, Australia), Thomas von Rintelen (Museum für Naturkunde, Leibniz Institute for Evolution and Biodiversity Science, Invalidenstr. 43, 10115 Berlin, Germany), Ian Watkinson (Department of Earth Sciences, Royal Holloway University of London, Egham, Surrey TW20 0EX, UK), Nigel Wattrus (Large Lakes Observatory, University of Minnesota Duluth, Duluth, MN 55812, USA), Satrio Wicaksono (Department of Earth, Environmental, and Planetary Sciences, Brown University, 324 Brook St., Providence, RI 02912, USA), Thomas Wonik (Liebniz Institute for Applied Geophysics, Stilleweg 2, 30655 Hanover, Germany), Alan Deino (Berkeley Geochronology Center, Berkeley, CA 94709, USA), Adianto M. Imran (Geological Department, Universitas Hasanuddin, Kampus
UNHAS Tamalanrea, Makassar, 90245, Indonesia), Ristiyani Marwoto (Research Center for Limnology, Indonesian Insitute of Sciences (LIPI), Jl. Raya Bogor m 46, Cibinong, 16911, West Java, Indonesia), La Ode Ngkoimani (Faculty of Earth Sciences and Technology, Haluoleo University, Kampus Baru Unhalu Anduoonoho, Kendari, 93232, Indonesia), La Ode Safiuddin (Faculty of Earth Sciences and Technology, Haluoleo University, Kampus Baru Unhalu Anduoonoho, Kendari, 93232, Indonesia), Gerald Tamuntuan (Department of Physics, Faculty of Mathematics and Natural Sciences, Sam Ratulangi University, Jl. Kampus Unsrat, Manado, 95114, Indonesia).

Author contributions. AV designed the study; sampled in the field; extracted vivianite crystals; actively took part in SEM, TEM, and XRD analyses; designed the figures; and led the writing of the paper. AF sampled in the field and measured pore water geochemistry. RW operated the TEM. JAS and FvB processed and measured iron isotopes. AMS led XRD analyses. HK led SEM analyses. AL led TOC analyses. KWB processed and measured samples for total iron and pore water iron. SN measured $\mathrm{pH}$ in the field. RS measured alkalinity in the field. LO sampled in the field and processed cores at LacCore. DA processed and sampled cores at LacCore. $\mathrm{CH}$ fulfilled the research permit procedure. As principal investigators of the Towuti Drilling Project, JMR, SB, and HV sampled in the field, processed drill core splitting and imaging at LacCore, processed TOC and Fe concentrations on full cores, and supervised the writing of the paper. SAC sampled in the field, fulfilled the research permit procedure, and supervised iron analyses and writing of the paper. JK sampled in the field and at LacCore and supervised geochemical analyses and writing of the paper. The Towuti Drilling Project Science Team actively participated in drilling operations and processing of the cores at LacCore.

Competing interests. The authors declare that they have no conflict of interest.

Acknowledgements. This research was carried out with partial support from the International Continental Scientific Drilling Program (ICDP); the U.S. National Science Foundation (NSF); the German Research Foundation (DFG); the Swiss National Science Foundation (SNSF); PT Vale Indonesia; the Ministry of Research, Education, and Higher Technology of Indonesia (RISTEK); Brown University; the University of Minnesota; the University of Geneva; GFZ German Research Centre for Geosciences; the Natural Sciences and Engineering Research Council of Canada (NSERC); and Genome British Columbia. This study was financially and logistically supported by the DFG ICDP priority program through grants to Jens Kallmeyer (KA 2293/8-1) and Aurèle Vuillemin (VU 94/11), an SNSF grant to Aurèle Vuillemin (P2GEP2_148621), and an NSERC Discovery grant (0487) to Sean A. Crowe.

We thank PT Vale Indonesia, the U.S. Continental Scientific Drilling and Coordination Office, the U.S. National Lacustrine Core Repository, and DOSECC Exploration Services for logistical support. The research was carried out with permission from RISTEK, the Ministry of Trade of the Republic of Indonesia, the Natural Resources Conservation Center (BKSDA), and the Government of 
Luwu Timur of Sulawesi. We thank the Director of the Indonesia Research Center for Limnology (P2L) - Indonesian Institute of Sciences (LIPI), Tri Widiyanto, and his staff at P2L-LIPI for their administrative support in obtaining the Scientific Research Permit. Supervision by the scientific crew of LacCore during core splitting and subsampling is kindly acknowledged. We also thank Aan Diyanto, Axel J. Kitte, Anja Schreiber, Ilona Schäpan and Johannes Glodny for their assistance during field sampling, TEM and SEM analyses, and mineral extractions.

Financial support. This research has been supported by the Swiss National Science Foundation (grant no. P2GEP2_148621), the Deutsche Forschungsgemeinschaft (grant nos. VU 94/1-1 and KA 2293/8-1), and the Natural Sciences and Engineering Research Council of Canada (grant no. 0487).

The article processing charges for this open-access publication were covered by a Research

Centre of the Helmholtz Association.

Review statement. This paper was edited by Caroline P. Slomp and reviewed by three anonymous referees.

\section{References}

Ayris, P. M. and Delmelle, P.: The direct environmental effects of tephra emission, Bull. Volcanol., 74, 1905-1936, https://doi.org/10.1007/s00445-012-0654-5, 2012.

Bauer, K. W., Byrne, J., Kenward, P., Simister, R., Michiels, C., Friese, A., Vuillemin, A., Henny, C., Nomosatryo, S., Kallmeyer, J., Kappler, A., Smit, M., Francois, R., and Crowe, S. A.: Magnetite biomineralization in ferruginous waters and early Earth evolution, EarthArXiv Preprint, https://doi.org/10.31223/osf.io/prhuz, 39 pp., 2020.

Beard, B. L., Handler, R. M., Scherer, M. M., Wu, L., Czaja, A. D., Heimann, A., and Johnson, C. M.: Iron isotope fractionation between aqueous ferrous iron and goethite, Earth Planet. Sc. Lett., 295, 241-250, https://doi.org/10.1016/j.eps1.2010.04.006, 2010.

Bernal-Brooks, F. W., Dávalos-Lind, L., and Lind, O. T.: Seasonal and spatial variation in algal growth potential and growth-limiting nutrients in a shallow endorheic lake: Lake Pátzcuaro (Mexico), Lakes Reserv. Res. Manag., 8, 83-93, https://doi.org/10.1046/j.1320-5331.2003.00217.x, 2003.

Black, C. A. (Ed.): Methods of Soil Analysis: Test Methods for Evaluating Solid Waste, Physical/Chemical Methods, 9045B Soil and Waste $\mathrm{pH}$, American Society of Agronomy, Madison, USA, 5 pp., 1973.

Bocher, F., Géhin, A., Ruby, C., Ghanbaja, J., Abdelmoula, M., and Génin, J.-M. R.: Coprecipitation of $\mathrm{Fe}(\mathrm{II}-\mathrm{III})$ hydroxycarbonate green rust stabilized by phosphate adsorption, Solid State Sci., 6, 117-124, https://doi.org/10.1016/j.solidstatesciences.2003.10.004, 2004.

Bramburger, A. J., Hamilton, P. B., Hehanussa, P. E., and Haffner, G. D.: Processes regulating the community composition and relative abundance of taxa in the diatom communities of the Malili
Lakes, Sulawesi Island, Indonesia, Hydrobiologia, 615, 215224, https://doi.org/10.1007/s10750-008-9562-2, 2008.

Brantley, S. L., Liermann, L., and Bullen, T. D.: Fractionation of $\mathrm{Fe}$ isotopes by soil microbes and organic acids, Geology, 29, 535-538, https://doi.org/10.1130/00917613(2001)029<0535:FOFIBS>2.0.CO;2, 2001.

Brewer, P. G. and Spencer, D. W.: Colorimetric determination of manganese in anoxic waters, Limnol. Oceanogr., 16, 107-110, https://doi.org/10.4319/lo.1971.16.10107,1971.

Bullen, T. D., White, A. F., Childs, C. W., Vivit, D. V., and Schulz, M. S.: Demonstration of significant abiotic iron isotope fractionation in nature, Geology, 29, 699-702, https://doi.org/10.1130/00917613(2001)029<0699:DOSAII>2.0.CO;2, 2001.

Busigny, V., Planavsky, N. J., Jézéquel, D., Crowe, S., Louvat, P., Moureau, J., Viollier, E., and Lyons, T. W.: Iron isotopes in an Archean ocean analogue, Geochim. Cosmochim. Ac., 133, 443462, https://doi.org/10.1016/j.gca.2014.03.004, 2014.

Clavero, V., Garcia, M., Fernández, J. A., and Niell, F. X.: Adsorption-desorption of phosphate and its availability in the sediment of a saline lake (Fuente de Piedra, southern Spain), Int. J. Salt Lake Res., 2, 153-163, https://doi.org/10.10007/BF02905907, 1993.

Compton, J., Mallinson, D., Glenn, C. R., Filippelli, G., Föllmi, K., Shields, G., and Zanin, Y.: Variations in the global phosphorus cycle, SEPM Spec. P., 66, 21-33, https://doi.org/10.2110/pec.00.66.0021, 2010.

Costa, K. M., Russell, J. M., Vogel, H., and Bijaksana, S.: Hydrological connectivity and mixing of Lake Towuti, Indonesia, in response to paleoclimatic changes over the last 60000 years, Palaeogeogr. Palaeocl., 417, 467-475, https://doi.org/10.1016/j.palaeo.2014.10.009, 2015.

Crosby, H. A., Roden, E. E., Johnson C. M., and Beard, B. L.: The mechanisms of iron isotope fractionation produced during dissimilatory $\mathrm{Fe}(\mathrm{III})$ reduction by Shewanella putrefaciens and Geobacter sulfurreducens, Geobiology, 5, 169-189, https://doi.org/10.1111/j.1472-4669.2007.00103.x, 2007.

Crowe, S. A., Pannalal, S. J., Fowle, D. A., Cioppa, M. T., Symons, D. T. A., Haffner, G. D., and Fryer, B. J.: Biogeochemical cycling in Fe-rich sediments from Lake Matano, Indonesia, Int. Symp. Water-Rock Interact., 11, 1185-1189, 2004.

Crowe, S. A., Katsev, S., Hehanussa, P., Haffner, G. D., Sundby, B., Mucci, A., and Fowle, D. A.: The biogeochemistry of tropical lakes: A case study from Lake Matano, Indonesia, Limnol. Oceanogr., 53, 319-331, https://doi.org/10.4319/lo.2008.53.1.0319, 2008.

Dauphas, N., John, S. G., and Rouxel, O.: Iron isotope systematics, Rev. Mineral. Geochem., 82, 415-510, https://doi.org/10.2138/rmg.2017.82.11, 2017.

Dijkstra, N., Slomp, C. P., Behrends, T., and Expedition 347 Scientists: Vivianite is a key sink for phosphorus in sediments of the Landsort Deep, an intermittently anoxic deep basin in the Baltic Sea, Chemic. Geol., 438, 58-72, https://doi.org/10.1016/j.chemgeo.2016.05.025, 2016.

Egger, M., Jilbert, T., Behrends, T., Rivard, C., and Slomp, C. P.: Vivianite is a major sink for phosphorus in methanogenic coastal surface sediments, Geochim. Cosmochim. Ac., 169, 217-235, https://doi.org/10.1016/j.gca.2015.09.012, 2015. 
Fagel, N., Alleman, L. Y., Granina, L., Hatert, F., Thamo-Bozso, E., Cloots, R., and Andre, L.: Vivianite formation and distribution in Lake Baikal sediments, Glob. Planet. Change, 46, 315-336, https://doi.org/10.1016/j.gloplacha.2004.09.022, 2005.

Ferris, F. G., Fyfe, W. S., and Beveridge, T. J.: Bacteria as nucleation sites for authigenic minerals in a metal-contaminated lake sediment, Chem. Geol., 63, 252-232, https://doi.org/10.1016/B9780-444-88900-3.50035-7, 1987.

Fredrickson, J. K., Zachara, J. M., Kennedy, D. W., Dong, H., Onstott, T. C., Hinman, N. W., and Li, S.: Biogenic iron mineralization accompanying the dissimilatory reduction of hydrous ferric oxide by a groundwater bacterium, Geochim. Cosmochim. Ac., 62, 3239-3257, https://doi.org/10.1016/S0016-7037(98)002439, 1998.

Friese, A., Kallmeyer, J. Kitte J. A., Montaño Martinez, I., Bijaksana, S., Wagner, D., the ICDP Lake Chalco Drilling Science Team, and the ICDP Towuti Drilling Science Team: A simple and inexpensive technique for assessing contamination during drilling operations, Limnol. Oceanogr. Methods, 15, 200-211, https://doi.org/10.1002/lom3.10159, 2017.

Friese, A., Kallmeyer, J. Glombitza, C., Vuillemin, A., Simister, R., Nomosatryo, S., Bauer, K., Heuer, V. B., Henny, C., Crowe, S. A., Ariztegui, D., Bijaksana, S., Vogel, H., Melles, M., Russell, J. M., and Wagner, D.: Methanogenesis predominates organic matter remineralization in a ferruginous, non-sulfidic sedimentary environment, EGU General Assembly Conference Abstracts, 20, EGU2018-7446, 2018.

Gächter, R., Meyer, J. S., and Mares, A.: Contribution of bacteria to release and fixation of phosphorus in lake sediments, Limnol. Oceanogr., 33, 1542-1558, https://doi.org/10.4319/lo.1988.33.6_part_2.1542, 1988.

Gächter, R. and Müller, B.: Why the phosphorus retention of lakes does not necessarily depend on the oxygen supply to their sediment surface, Limnol. Oceanogr., 48, 929-933, https://doi.org/10.4319/lo.2003.48.2.0929, 2003.

Glasauer, S., Weidler, P. G., Langley, S., and Beveridge, T. J.: Controls on Fe reduction and mineral formation by a subsurface bacterium, Geochim. Cosmochim. Ac., 67, 1277-1288, https://doi.org/10.1016/S0016-7037(02)01199-7, 2003.

Golightly, J. P.: Progress in understanding the evolution of nickel laterites, in: The Challenge of Finding New Mineral Resources - Global Metallogeny, Innovative Exploration, and New Discoveries, Special Publication 15, Society of Economic Geologists, Denver, United-States, 451-485, 2010.

Golubev, S. V., Bénézeth, P., Schott, J., Dandurand, J. L., and Castillo, A.: Siderite dissolution kinetics in acidic aqueous solutions from 25 to $1000^{\circ} \mathrm{C}$ and 0 to $50 \mathrm{~atm} p \mathrm{CO}_{2}$, Chem. Geol., 265, 13-19, https://doi.org/10.1016/j.chemgeo.2008.12.031, 2009.

Haffner, G. D., Hehanussa, P. E., and Hartoto, D.: The biology and physical processes of large lakes of Indonesia: Lakes Matano and Towuti, in: The Great Lakes of the World (GLOW): Food-Web, Health, and Integrity, edited by: Munawar, M. and Hecky, R. E., Blackhuys, 183-194, 2001.

Halevy, I., Alesker, M., Schuster, E. M., Popovitz-Biro, R., and Feldman, Y.: A key role for green rust in the Precambrian oceans and the genesis of iron formations, Nat. Geosci., 10, 135-139, https://doi.org/10.1038/ngeo2878, 2017.
Hansen, H. C. B. and Poulsen, I. F.: Interaction of synthetic sulphate "green rust" with phosphate and the crystallization of vivianite, Clay. Clay Miner., 47, 312-318, 1999.

Hanzel, D., Melsel, W., Hanzel, D., and Gütlich, P.: Mössbauer effect study of the oxidation of vivianite, Solid State Commun., 76, 307-310, https://doi.org/10.1016/0038-1098(90)90843-Z, 1990.

Harper, M., Howorth, R., and McLeod, M.: Late Holocene diatoms in Lake Poukawa: Effects of airfall tephra and changes in depth, New Zeal. J. Mar. Fresh., 20, 107-118, https://doi.org/10.1080/00288330.1986.9516135, 1986.

Hasberg, A. K. M., Bijaksana, S., Held, P., Just, J., Melles, M., Morlock, M. A., Opitz, S., Russell, J. M., Vogel, H., and Wennrich, V.: Modern sedimentation processes in Lake Towuti, Indonesia, revealed by the composition of surface sediments, Sedimentology, 66, 675-698, https://doi.org/10.1111/sed.12503, 2019.

Henkel, S., Kasten, S., Poulton, S. W., and Staubwasser, M.: Determination of the stable iron isotopic composition of sequentially leached iron phases in marine sediments, Chem. Geol. 421, 93102, https://doi.org/10.1016/j.chem.geo.2015.12.003, 2016.

Herschy, B., Chang, S. J., Blake, R., Lepland, A., Abbott-Lyon, H., Sampson, J., Atlas, Z., Kee, T. P., and Pasek, M. A.: Archean phosphorus liberation induced by iron redox geochemistry, Nat. Commun., 9, 1346, https://doi.org/10.1038/s41467-018-038353, 2018 .

Holland, H. D.: The oxygenation of the atmosphere and oceans, Philos. T. Roy. Soc. B, 361, 903-915, https://doi.org/10.1098/rstb.2006.1838, 2006.

Hupfer, M. and Lewandowski, J.: Oxygen controls the phosphorus release from lake sediments - a long-lasting paradigm in limnology, Int. Rev. Hydrobiol., 93, 415-432, https://doi.org/10.1002/iroh.200711054, 2008.

Jenkins, S. R. and Moore, R. C.: A proposed modification to the classical method of calculating alkalinity in natural waters, J. Am. Water Works Ass. 69, 56-60, https://doi.org/10.1002/j.1551-8833.1977.tb02544.x, 1977.

Johnson, C. M., Roden, E. E., Welch, S. A., and Beard, B. L.: Experimental constraints on $\mathrm{Fe}$ isotope fractionation during magnetite and Fe carbonate formation coupled to dissimilatory hydrous ferric oxide reduction, Geochem. Cosmochem. Ac., 69, 963-993, https://doi.org/10.1016/j.gca.2004.06.043, 2005.

Johnson, C. M., Ludois, J. M., Beard, B. L., Beukes, N. J., and Heimann, A.: Iron formation carbonates: Paleoceanographic proxy or recorder of microbial diagenesis? Geology, 41, 11471150, https://doi.org/10.1130/G34698.1, 2013.

Johnson, C. A., Murayama, M., Küsel, K., and Hochella, M. F. Jr.: Polycrystallinity of green rust minerals and their synthetic analogs: Implications for particle formation and reactivity in complex systems, Am. Mineral., 100, 2091-2105, https://doi.org/10.2138/am-2015-5287, 2015.

Jones, C., Crowe, S. A., Sturm, A., Leslie, K. L., MacLean, L. C. W., Katsev, S., Henny, C., Fowle, D. A., and Canfield, D. E.: Biogeochemistry of manganese in ferruginous Lake Matano, Indonesia, Biogeosciences, 8, 2977-2991, https://doi.org/10.5194/bg-8-2977-2011, 2011.

Jones, C., Nomosatryo, S., Crowe, S. A., Bjerrum, C. J., and Canfield, D. E.: Iron oxides, divalent cations, silica, and the early earth phosphorus crisis, Geology, 43, 135-138, https://doi.org/10.1130/G36044.1, 2015. 
Katsev, S., Tsandev, I., L'Heureux, I., and Rancourt, D. G.: Factors controlling long-term phosphorus efflux from lake sediments: Exploratory reactive-transport modeling, Chem. Geol., 234, 127-147, https://doi.org/10.1016/j.chemgeo.2006.05.001, 2006.

Katsev, S., Crowe, S. A., Mucci, A., Sundby, B., Nomosatryo, S., Haffner, G. D., and Fowle, D. A.: Mixing and its effects on biogeochemistry in the persistently stratified, deep, tropical Lake Matano, Indonesia, Limnol. Oceanogr., 55, 763-776, https://doi.org/10.4319/lo.2010.55.2.0763, 2010.

Kipp, M. A. and Stüeken, E. E.: Biomass recycling and Earth's early phosphorus cycle, Sci. Adv., 3, eaao4795, https://doi.org/10.1126/sciadv.aao4795, 2017.

Konhauser, K. O., LaLonde, S. V., Amskold, L., and Holland, H. D.: Was there really an Archean phosphate crisis?, Science, 315, 1234, https://doi.org/10.1126/science.1136328, 2007.

Lehmusluoto, P., Machbub, B., Terangna, N., Rumiputro, S., Achmad, F., Boer, L., Brahmana, S. S., Priadi, B., Setiadji, B., Sayuman, O., and Margana, A.: National inventory of the major lakes and reservoirs in Indonesia, General limnology, Expedition Indodanau Technical Report, 71 pp., 1995.

Lemos, V. P., da Costa, M. L., Lemos, R. L., and de Faria, M. S. G.: Vivianite and siderite in lateritic iron crust: an example of bioreduction, Quim. Nova, 30, 36-40, https://doi.org/10.1590/S010040422007000100008, 2007.

Lenstra, W. K., Egger, M., van Helmond, N. A. G. M., Kritzberg, E., Conley, D. J., and Slomp, C. P.: Large variations in iron input to an oligotrophic Baltic Sea estuary: impact on sedimentary phosphorus burial, Biogeosciences, 15, 6979-6996, https://doi.org/10.5194/bg-15-6979-2018, 2018.

Manheim, F. T.: A hydraulic squeezer for obtaining interstitial water from consolidated and unconsolidated sediments, USGS Reference Paper, 550, 171-174, 1966.

Liu, K., Wu, L. L., Couture, R. M., Li, W. Q., and Van Cappellen, P.: Iron isotope fractionation in sediments of an oligotrophic freshwater lake, Earth Planet. Sc. Lett., 423, 164-172, https://doi.org/10.1016/j.epsl.2015.05.010, 2015.

Maher, B. A., Alekseev, A., and Alekseeva, T.: Magnetic mineralogy of soils across the Russian Steppe: climatic dependence of pedogenic magnetite formation, Palaeogeogr. Palaeocl. 201, 321-341, https://doi.org/10.1016/S0031-0182(03)00618-7, 2003.

Manning, P. G., Murphy, T. P., and Prepas, E. E.: Intensive formation of vivianite in the bottom sediments of mesotrophic Narrow Lake, Alberta, Can. Mineral., 29, 77-85, 1991.

Michiels, C. C., Darchambeau, F., Roland, F. A., Morana, C., Llirós, M., Garcia-Armisen, T., Thamdrup, B., Borges, A. V., Canfield, D. E., Servais, P., Descy, J.-P., and Crowe, S. A.: Irondependent nitrogen cycling in a ferruginous lake and the nutrient status of Proterozoic oceans, Nat. Geosci., 10, 217-221, https://doi.org/10.1038/NGO2886, 2017.

Morlock, M. A., Vogel, H., Nigg, V., Ordoñez, L., Hasberg, A. K. M., Melles, M., Russell, J. M., Bijaksana, S., and the TDP Science Team: Climatic and tectonic controls on source-to-sink processes in the tropical, ultramafic catchment of Lake Towuti, Indonesia, J. Paleolimnol., 61, 279-295, https://doi.org/10.1007/s10933-018-0059-3, 2019.

Murphy, J. and Riley, J. P.: A modified single solution method for the determination of phosphate in natural waters, Anal. Chim.
Acta, 27, 31-36, https://doi.org/10.1016/S0003-2670(00)884445,1962 .

Nomosatryo, S., Henny, C., Jones, C. A., Michiels, C., and Crowe, S. A.: Karaketristik dan klasifikasi trofik di Danau Matano dan Danau Towuti Sulawesi selatan, Perkembangan Limnologi dalam Mendukung Pembangunan Berkelanjutan di Indonesia: Tantangan dan Harapan, Prosiding Pertemuan Ilmiah Tahunan MLI I, 493-507, 2013.

Nanzyo, M., Takahashi, T., Sato, A., Shoji, S., and Yamada, I: Dilute acid-soluble phosphorus in fresh airborne tephras and fixation with an increase in active aluminium and iron, Soil Sci. Plant. Nutr., 43, 839-848, https://doi.org/10.1080/00380768.1997.10414650, 1997.

O’Loughlin, E. J., Boyanov, M. I., Flynn, T. M., Gorski, C. A., Hofmann, S. M., McCormick, M. L., Scherer, M. M., and Kemner, K. M.: Effects of bound phosphate on the bioreduction of lepidocrocite $(\mathrm{y}-\mathrm{FeOOH})$ and maghemite $\left(\mathrm{y}-\mathrm{Fe}_{2} \mathrm{O}_{3}\right)$ and formation of secondary minerals, Environ. Sci. Technol., 47, 9157-9166, https://doi.org/10.1021/es400627j, 2013.

Ordoñez, L., Vogel, H., Sebag, D., Ariztegui, D., Adatte, T., Russell, J. M., Kallmeyer, J., Vuillemin, A., Friese, A., Crowe, S. A., Bauer, K. W., Simister, R., Nomosatryo, S., Henny, C., and Bijaksana, S.: Empowering conventional Rock-Eval pyrolysis for organic matter characterization of the siderite-rich sediments of Lake Towuti (Indonesia) using End-Member Analysis, Org. Geochem., 134, 32-44, https://doi.org/10.1016/j.orggeochem.201905.002, 2019.

Parkhurst, D. L. and Appelo, C. A. J. (Eds.): Description of input and examples for PHREEQC version 3 - A computer program for speciation, batch-reaction, one-dimensional transport, and inverse geochemical calculations, book 6, chapter A43: U.S. Geological Survey Techniques and Methods, Denver, USA, 2013.

Percak-Dennett, E. M., Loizeau, J. L., Beard, B. L., Johnson, C. M., and Roden, E. E.: Iron isotope geochemistry of biogenic magnetite-bearing sediments from the Bay of Vidy, Lake Geneva, Chem. Geol., 360, 32-40, https://doi.org/10.1016/j.chemgeo.2013.10.008, 2013.

Posth, N. R., Canfield, D. E., and Kappler, A.: Biogenic $\mathrm{Fe}$ (III) minerals: from formation to diagenesis and preservation in the rock record, Earth-Sci. Rev., 135, 103-121, https://doi.org/10.1016/j.earscirev.2014.03.012, 2014.

Postma, D.: Formation of siderite and vivianite and the pore water composition of a recent bog sediment in Denmark, Chem. Geol., 31, 225-244, https://doi.org/10.1016/00092541(80)90088-1, 1981.

Poulton, S. W. and Canfield, D. E.: Development of a sequential extraction procedure for iron: implications for iron partitioning in continentally derived particulates, Chem. Geol., 214, 209-221, https://doi.org/10.1016/j.chemgeo.2004.09.003, 2005.

Recasens, C., Ariztegui, D., Maidana, N. I., Zolitschka, B., and the PASADO Science Team: Diatoms as indicators of hydrological and climatic changes in Laguna Potrok Aike (Patagonia) since the Late Pleistocene, Palaeogeogr. Palaeocl., 417, 309-319, https://doi.org/10.1016/j.palaeo.2014.09.021.

Reed, D. C., Slomp, C. P., and Gustafsson, B. G.: Sedimentary phosphorus dynamics and the evolution of bottom-water hypoxia: A coupled benthic-pelagic model of a coastal system, Limnol. Oceanogr., 56, 1075-1092, https://doi.org/10.4319/lo.2011.56.3.1075, 2011. 
Reed, D. C., Gustafsson, B. G., and Slomp, C. P.: Shelf-tobasin iron shuttling enhances vivianite formation in deep Baltic Sea sediments, Earth Planet. Sc. Lett., 434, 241-251, https://doi.org/10.1016/j.epsl.2015.11.033, 2016.

Refait, P., Reffass, M., Landoulsi, J., Sabot, R., and Jeannin, M.: Role of phosphate species during the formation and transformation of the Fe(II-III) hydroxycarbonate green rust, Colloid. Surface A., 299, 29-37, https://doi.org/10.1016/j.colsurfa.2006.11.013, 2007.

Reimers, C. E., Ruttenberg, K. C., Canfield, D. E., Christiansen, M. B., and Martin, J. B.: Porewater pH and authigenic phases formed in the uppermost sediments of the Santa Barbara Basin, Geochim. Cosmochim. Ac., 60, 4037-4057, https://doi.org/10.1016/S0016-7037(96)00231-1,1996.

Roden, E. E. and Edmonds, J. W.: Phosphate mobilization in iron-rich anaerobic sediments: microbial Fe(III) oxide reduction versus iron-sulfide formation, Arch. Hydrobiol., 139, 347-378, ISSN: 0003-9136, 1997.

Rothe, M., Frederichs, T., Eder, M., Kleeberg, A., and Hupfer, M.: Evidence for vivianite formation and its contribution to long-term phosphorus retention in a recent lake sediment: a novel analytical approach, Biogeosciences, 11, 5169-5180, https://doi.org/10.5194/bg-11-5169-2014, 2014.

Rothe, M., Kleeberg, A., Grüneberg, B., Friese, K., PérezMayo, M., and Hupfer, M.: Sedimentary sulphur:iron ratio indicates vivianite occurrence: A study from two contrasting freshwater systems, PLoS ONE, 10, e0143737, https://doi.org/10.1371/journal.pone.0143737, 2015.

Rothe, M., Kleeberg, A., and Hupfer, M.: The occurrence, identification and environmental relevance of vivianite in waterlogged soils and aquatic sediments, Earth Sci. Rev., 158, 51-64, https://doi.org/10.1016/j.earscirev.2016.04.008, 2016.

Russell, J. M., Vogel, H., Konecky, B. L., Bijaksana, S., Huang, Y., Melles, M., Wattrus, N., Costa, K., and King, J. W.: Glacial forcing of central Indonesian hydroclimate since 60000 yr B.P., P. Natl. Acad. Sci., 111, 5100-5105, https://doi.org/10.1073/pnas.1402373111, 2014.

Russell, J. M., Bijaksana, S., Vogel, H., Melles, M., Kallmeyer, J., Ariztegui, D., Crowe, S., Fajar, S., Hafidz, A., Haffner, D., Hasberg, A., Ivory, S., Kelly, C., King, J., Kirana, K., Morlock, M., Noren, A., O'Grady, R., Ordonez, L., Stevenson, J., von Rintelen, T., Vuillemin, A., Watkinson, I., Wattrus, N., Wicaksono, S., Wonik, T., Bauer, K., Deino, A., Friese, A., Henny, C., Imran, Marwoto, R., Ngkoimani, L. O., Nomosatryo, S., Safiuddin, L. O., Simister, R., and Tamuntuan, G.: The Towuti Drilling Project: Paleoenvironments, biological evolution, and geomicrobiology of a tropical Pacific lake, Sci. Dri., 21, 29-40, https://doi.org/10.5194/sd-21-29-2016, 2016.

Sánchez-Román, M., Puente-Sánchez F., Parro, V., and Amils, R.: Nucleation of Fe-rich phosphate and carbonate on microbial cells and exoplymeric substances, Front. Microbiol., 6, 1024, https://doi.org/10.3389/fmicb.2015.01024, 2015.

Sapota, T., Aldahan, A., and Al-Aasm, I. S.: Sedimentary facies and climate control of formation of vivianite and siderite microconcretions in sediments of Lake Baikal, Siberia, J. Paleolimnol., 36, 245-257, https://doi.org/10.1007/s10933-006-9005-x, 2006.

Schoenberg, R. and von Blanckenburg, F.: An assessment of the accuracy of stable $\mathrm{Fe}$ isotope ratio measurements on samples with organic and inorganic matrices by high-resolution multicollector ICP-MS, Int. J. Mass Spectrom., 242, 257-272, https://doi.org/10.1016/j.ijms.2004.11.025, 2005.

Scholz, F., Severmann, S., McManus, J., Noffke, A., Lomnitz, U., and Hensen, C.: On the isotope composition of reactive iron in marine sediments: Redox shuttle versus early diagenesis, Chem. Geol., 389, 48-59, https://doi.org/10.1016/j.chemgeo.2014.09.009, 2014.

Schütt, B.: Reconstruction of Holocene paleoenvironments in the endorheic basin of Laguna de Gallocanta, Central Spain by investigation of mineralogical and geochemical characters from lacustrine sediments J. Paleolimnol. 20, 217-234, https://doi.org/10.1023/A:1007924000636, 1998.

Severmann, S., Johnson, C. M., Beard, B. L., and McManus, J.: The effect of early diagenesis on the Fe isotope compositions of porewaters and authigenic minerals in continental margin sediments, Geochim. Cosmochim. Ac., 70, 2006-2022, https://doi.org/10.1016/j.gca.2006.01.007, 2006.

Seward, R. W. (Ed.): NBS Standard Reference Material Catalog NBS, Special Publication 260, National Bureau of Standards, Gaithersburg, USA, 1986.

Shaffer, G.: Phosphate pumps and shuttles in the Black Sea, Nature 321, 515-517, https://doi.org/10.1038/321515a0, 1986.

Sheppard, R. Y., Milliken, R. E., Russell, J. M., Darby Dyar, M., Sklute, E. C., Vogel, H., Melles, M., Bijaksana, S., Morlock, M. A., and Hasberg, A. K. M.: Characterization of iron in Lake Towuti sediment, Chem. Geol., 512, 11-30, https://doi.org/10.1016/j.chemgeo.2019.02.029, 2019.

Singh, B., Sherman, D. M., Gilkes, R. J., Wells, M., and Mosselmans, J. F. W.: Structural chemistry of $\mathrm{Fe}, \mathrm{Mn}$, and $\mathrm{Ni}$ in synthetic hematites as determined by extended X-ray absorption fine structure spectroscopy, Clay Clay Miner., 48, 521-527, https://doi.org/10.1346/CCMN.2000.0480504, 2000.

Skulan, J. L., Beard, B. L., and Johnson, C. M.: Kinetic and equilibrium $\mathrm{Fe}$ isotope fractionation between aqueous $\mathrm{Fe}(\mathrm{III})$ and hematite, Geochim. Cosmochim. Ac., 66, 2995-3015, https://doi.org/10.1016/S0016-7037(02)00902-X, 2002.

Song, L. T., Liu, C., Wang, Z., Zhu, X., Teng, Y., Wang, J., Tang, S., Li, J., and Liang, L.: Iron isotope compositions of natural river and lake samples in the karst area, Guizhou Province, Southwest China, Acta Geol. Sin.-Engl., 85, 712-722, https://doi.org/10.1111/j.1755-6724.2011.00464.x, 2011.

Stamatakis, M. G. and Koukouzas, N. K.: The occurrence of phosphate minerals in lacustrine clayey diatomite deposits, Thessaly, Central Greece, Sediment. Geol., 139, 33-47, https://doi.org/10.1016/S0037-0738(00)00154-8, 2001.

Stookey, L. L.: Ferrozine - A new spectrophotometric reagent for iron, Anal. Chem., 42, 779-781, doi.org/10.1021/ac60289a016, 1970 .

Staubwasser, M., von Blanckenburg, F., and Schoenberg, R.: Iron isotopes in the early marine diagenetic iron cycle, Geology, 34, 629-632, https://doi.org/10.1130/622647.1, 2006.

Tamuntuan, G., Bijaksana, S., King, J., Russell, J., Fauzi, U., and Maryunani, K.: Variation of magnetic properties in sediments from Lake Towuti, Indoensia, and its paleoclimatic significance, Palaeogeogr. Palaeocl., 420, 163-172, https://doi.org/10.1016/j.palaeo.2014.12.008, 2015.

Tangalos, G. E., Beard, B. L., and Johnson, C. M.: Microbial production of isotopically light iron(II) in a modern chemically precipitated sediment and implications for iso- 
topic variations in ancient rocks, Geobiology, 8, 197-208, https://doi.org/10.1111/j.1472-4669.2010.00237.x, 2010.

Teutsch, N., Schmid, M., Müller, B., Halliday, A. N., Bürgmann, H., and Wehrli, B.: Large iron isotope fractionation at the oxicanoxic boundary in Lake Nyos, Earth Planet. Sc. Lett., 285, 5260, https://doi.org/10.1016/j.eps1.2009.05.044, 2009.

Van der Grinten, E., Janssen, M., Simis, S. G. H., Barranguet, C., and Admiraal, W.: Phosphate regime structures species composition in cultured phototrophic biofilms, Freshwater Biol., 49, 369 381, https://doi.org/10.1111/j.1365-2427.01189.x, 2004.

Vogel, H., Russell, J. M., Cahyarini, S. Y., Bijaksana, S., Wattrus, N., Rethemeyer, J., and Melles, M.: Depositional modes and lake-level variability at Lake Towuti, Indonesia, during the past $\sim 29 \mathrm{kyr}$ BP, J. Paleolimnol., 54, 359-377, https://doi.org/10.1016/S0883-2927(99)00097-9, 2015.

Vodyanitskii, Y. N., and Shoba, S. A.: Ephemeral $\mathrm{Fe}(\mathrm{II}) / \mathrm{Fe}(\mathrm{III})$ layered double hydroxides in hydromorphic soils: A review, Eurasian Soil Sci., 48, 240-249, https://doi.org/10.1134/S10642293150, 2015.

Viollier, E., Inglett, P. W., Hunter, K., Roychoudhury, A. N., and Van Cappellen P.: The ferrozine method revisited: $\mathrm{Fe}(\mathrm{II}) / \mathrm{Fe}(\mathrm{III})$ determination in natural waters, Appl. Geochem., 15, 785-790, https://doi.org/10.1016/S0883-2927(99)00097-9, 2000.

von Blanckenburg, F., Marnberti, M., Schoenberg, R., Kamber, B. S., and Webb, G. E.: The iron isotope composition of microbial carbonate, Chem. Geol., 249, 113-128, https://doi.org/10.1016/j.chemgeo.2007.12.001, 2008.

von Blanckenburg, F., Wittmann, H., and Schuessler, J. A.: HELGES: Helmholtz Laboratory for the Geochemistry of the Earth Surface, Journal of Large-Scale Research Facilities, 2, A84, https://doi.org/10.17815/jlsrf-2-141, 2016.

Vuillemin, A., Ariztegui, D., Coninck, A., Lücke, A., Mayr, C., Schubert, C., and the PASADO Scientific Team: Origin and significance of diagenetic concretions in sediments of Laguna Potrok Aike, southern Argentina, J. Paleolimnol., 50, 275-291, https://doi.org/10.1007/s10933-013-9723-9, 2013.

Vuillemin, A., Ariztegui, D., Lücke, A., Mayr, C., and the PASADO Science Team: Paleoenvironmental conditions define current sustainability of microbial populations in Laguna Potrok Aike, Argentina, Aquat. Sci., 76, 101-114, https://doi.org/10.1007/s00027-013-0317-4, 2014.

Vuillemin, A., Friese, A., Alawi, M., Henny, C., Nomosatryo, S., Wagner, D., Crowe, S. A., and Kallmeyer, J.: Geomicrobiological features of ferruginous sediments from Lake Towuti, Indonesia, Front. Microbiol., 7, e1007, https://doi.org/10.3389/fmicb.2016.01007, 2016.

Vuillemin, A., Horn, F., Alawi, M., Henny, C., Wagner, D., Crowe, S. A., and Kallmeyer, J.: Preservation and significance of extracellular DNA in ferruginous sediments from Lake Towuti, Indonesia, Front. Microbiol., 8, e1440, https://doi.org/10.3389/fmicb.2017.01440, 2017.
Vuillemin, A., Horn, F., Friese, A., Winkel, M., Alawi, M., Wagner, D., Henny, C., Orsi, W. D., Crowe, S. A., and Kallmeyer, J.: Metabolical potential of microbial communities from ferruginous sediments. Environ. Microbiol., 20, 4297 4313, https://doi.org/10.1111/1462-2920.1443, 2018.

Vuillemin, A., Wirth, R., Kemnitz, H., Schleicher, A. M., Friese, A., Bauer, K. W., Simister, R., Nomosatryo, S., Ordoñez, L., Ariztegui, D., Henny, C., Crowe, S. A., Benning, L. G., Kallmeyer, J., Russell, J. M., Bijaksana, S., Vogel, H., and the Towuti Drilling Project Science Team: Formation of diagenetic siderite in modern ferruginous sediments, Geology, 47, 540-544, https://doi.org/10.1130/G46100.1, 2019a.

Vuillemin, A., Friese, A., Lücke, A., Bauer, K. W., Nomosatryo, S., Simister, R., Ordoñez, L. G., Ariztegui, D., Russell, J. M., Bijaksana, S., Vogel, H., Crowe, S. A., Kallmeyer, J., and the Towuti Drilling Project Science Team: Pore water geochemistry and bulk sediment measurements of downcore profiles from site TDP-1A of the ICDP Towuti Drilling Project, Lake Towuti, Indonesia, Dataset, 908080, https://doi.org/10.1594/PANGAEA.908080, 2019b.

Wilson, T. A., Amirbahman, A., Norton, S. A., and Voytek, M. A.: A record of phosphorus dynamics in oligotrophic lake sediment, J. Paleolimnol., 44, 279-294, https://doi.org/10.1007/s10933-0099403-y, 2010.

Wirth, R.: Focused Ion Beam (FIB) combined with SEM and TEM: Advanced analytical tools for studies of chemical composition, microstructure and crystal structure in geomaterials on a nanometre scale, Chem. Geol., 261, 217-229, https://doi.org/10.1016/j.chemgeo.2008.05.019, 2009.

Wu, L. L., Beard, B. L., Roden, E. E., and Johnson, C. M.: Stable iron isotope fractionation between aqueous $\mathrm{Fe}$ (II) and hydrous ferric oxide, Environ. Sci. Technol. 45, 1847-1852, https://doi.org/10.1021/es103171x, 2011.

Zachara, J. M., Fredrickson, J. K., Li, S. M., Kennedy, D. W., Smith, S. C., and Gassman, P. L.: Bacterial reduction of crystalline $\mathrm{Fe}^{3+}$ oxides in single phase suspensions and subsurface materials, Am. Miner., 83, 1426-1443, https://doi.org/10.2138/am-1998-1105, 1998.

Zegeye, A., Bonneville, S., Benning, L. G., Sturm, A., Fowle, D. A., Jones, C., Canfield, D. E., Ruby, C., MacLean, L. C., Nomosatryo, S., Crowe, S. A., and Poulton, S. W.: Green rust formation controls nutrient availability in a ferruginous water column, Geology, 40, 599-602, https://doi.org/10.1130/G32959.1, 2012.

Zhang, Y. and Prepas, E. E.: Regulation of the dominance of planktonic diatoms and cyanobacteria in four eutrophic hardwater lakes by nutrients, water column stability, and temperature, Can. J. Fish. Aquat. Sci., 53, 621-633, https://doi.org/10.1139/f95205, 1996. 